\title{
A GIS and statistical approach to identify variables that control water quality in hydrothermally altered and mineralized watersheds, Silverton, Colorado, USA
}

\author{
Douglas B. Yager • Raymond H. Johnson • \\ Barnaby W. Rockwell · Jonathan Saul Caine • \\ Kathleen S. Smith
}

Received: 22 May 2012/Accepted: 11 December 2012/Published online: 12 February 2013

(C) The Author(s) 2013. This article is published with open access at Springerlink.com

\begin{abstract}
Hydrothermally altered bedrock in the Silverton mining area, southwest Colorado, USA, contains sulfide minerals that weather to produce acidic and metal-rich leachate that is toxic to aquatic life. This study utilized a geographic information system (GIS) and statistical approach to identify watershed-scale geologic variables in the Silverton area that influence water quality. GIS analysis of mineral maps produced using remote sensing datasets including Landsat Thematic Mapper, advanced spaceborne thermal emission and reflection radiometer, and a hybrid airborne visible infrared imaging spectrometer and fieldbased product enabled areas of alteration to be quantified. Correlations between water quality signatures determined at watershed outlets, and alteration types intersecting both total watershed areas and GIS-buffered areas along streams were tested using linear regression analysis. Despite remote sensing datasets having varying watershed area coverage due to vegetation cover and differing mineral mapping capabilities, each dataset was useful for delineating acidgenerating bedrock. Areas of quartz-sericite-pyrite mapped by AVIRIS have the highest correlations with acidic surface water and elevated iron and aluminum concentrations. Alkalinity was only correlated with area of acid neutralizing, propylitically altered bedrock containing calcite and chlorite mapped by AVIRIS. Total watershed area of acid-generating bedrock is more significantly correlated
\end{abstract}

Electronic supplementary material The online version of this article (doi:10.1007/s12665-013-2229-y) contains supplementary material, which is available to authorized users.

D. B. Yager $(\bowtie) \cdot$ R. H. Johnson - B. W. Rockwell •

J. S. Caine $\cdot$ K. S. Smith

U.S. Geological Survey, Denver, CO, USA

e-mail: dyager@usgs.gov with acidic and metal-rich surface water when compared with acid-generating bedrock intersected by GIS-buffered areas along streams. This methodology could be useful in assessing the possible effects that alteration type area has in either generating or neutralizing acidity in unmined watersheds and in areas where new mining is planned.

Keywords Watershed · Hydrothermal alteration . Water quality $\cdot$ GIS $\cdot$ Statistical analysis

\section{Introduction}

Abandoned mine lands (AML) investigations conducted by the U.S. Geological Survey between 1996 and 2001 in the Animas River watershed (ARW) near Silverton, Colorado, USA, resulted in one of the most comprehensive geodatasets for a watershed affected by hard-rock metallic mining (Church et al. 2007). Information on ARW geology, geophysics, geochemistry, hydrology, biology, remote sensing, base geographic, and digital terrain information is archived in a relational database and in geographic information system (GIS) coverage formats (Yager and Bove 2007; Sole and Rich 2007; Smith et al. 2007; Kimball et al. 2007; Bove et al. 2007a, b; Dalton et al. 2007). Several AML datasets were analyzed for this study. Federal land managers and the local ARW Stakeholders group are actively involved in remediation of abandoned mines in the ARW, a region that was the site of base-metal $(\mathrm{Cu}-\mathrm{Pb}-\mathrm{Zn})$ and precious-metal $(\mathrm{Ag}-\mathrm{Au})$ hard rock mining from the late 1870s to 1991. An extensive legacy of mining has left behind hundreds of mines and prospects. Weathering of mine waste and hydrothermally altered bedrock that hosts the metallic mineral deposits causes oxidation of sulfide minerals forming acidic and metal-rich leachate that 
adversely impacts water quality and is toxic to aquatic life (Church et al. 2007; DeGraff 2007).

A principal goal of this study was to analyze AML datasets to advance our understanding of the physical factors that control water quality at the watershed scale $\left(1.5-20 \mathrm{~km}^{2}\right)$. Knowledge of the most important variables that produce acid rock drainage (ARD) is especially useful to land managers and mining companies to aid in identifying areas posing the greatest environmental risks where new mining will occur and that may present reclamation challenges once mining ceases. In contrast, when watersheds have physical variables that can reduce acidity, such as rocks with acid neutralizing capacity (ANC), this information is also useful in mine site planning and remediation efforts, as it can be used to help mitigate acid mine drainage and sequester metals (Yager and Caine 2003; Yager et al. 2005, 2008a, b).

Geographic and geologic setting

The San Juan Mountains exhibit a wide diversity of ecological characteristics due to their mid-latitude location, high elevation, extreme topographic relief, and consequent ecosystem variability. The San Juan Mountains encompass subalpine parks, grasslands, and wetlands that contain multiple ecosystems including alpine, spruce fir; mixed conifer, ponderosa pine, oak, Douglas fir, and aspen forests; parks and meadowlands, mountain shrub, and pinon-juniper woodlands; and shrub-steppe communities (Chapman et al. 2006). Relatively high regional precipitation, occurring primarily as snow in the fall and winter, results in the critical water recharge area to the semi-arid Colorado River basin.

The geology of the western San Juan Mountains study area is exceptional in that many diverse rock types representing geologic eras from the Precambrian to Cenozoic are preserved. The general stratigraphy of the study area consists of Precambrian crystalline basement rocks overlain by Paleozoic to Tertiary sedimentary rocks and a voluminous Oligocene volcanic cover (Yager and Bove 2007). The volcano-tectonic framework of the study area consists of early intermediate composition volcanism overprinted by caldera-forming eruptions. An arcuate primary drainage network delineates structural margins of the San Juan and the nested Silverton calderas (Fig. 1). Structures that developed coincident with caldera collapse served as flow paths for hydrothermal fluids during several episodes of hydrothermal alteration and base- and precious-metal mineralization (Casadevall and Ohmoto 1977; Bove et al. 2001; Yager and Bove 2007). The northeasttrending Eureka graben served as an important flow path for mineralization and formed in response to caldera resurgence of the San Juan and Silverton caldera complex. Where not locally overprinted by intense hydrothermal alteration, a regional propylitic alteration assemblage containing calcite, chlorite, and epidote pervades the entire study area, locally supplying ANC and alkalinity to surface water (Yager et al. 2005, 2009; Yager 2008). The study area was extensively glaciated during the Pleistocene epoch and has high topographic relief ranging in elevation from $2,800 \mathrm{~m}$ to over $4,200 \mathrm{~m}$ providing for excellent bedrock exposures.

\section{Previous work}

Geochemical investigations in the study area

Issues addressed as part of past AML research included identifying the relative contributions of ARD and associated metal loads to surface water from mined watersheds and naturally altered and unmined areas. Research described in Bove et al. (2007b) focused on determining water quality geochemical characteristics of surface water and groundwater that is sourced in rocks having well-characterized geologic units and hydrothermal alteration types. Water sampled as part of the Bove et al. (2007b) study was classified as being either mining- or non-mining affected. Statistics were used to indicate the range in concentration for multiple metals, sulfate, and $\mathrm{pH}$. The study characterized the chemistry of waters sourced in highly and weakly altered rock types, but no attempt was made to determine how watershed water chemistry might be influenced as a function of differing proportions and types of watershed variables. Mast et al. (2000b) used a geochemical massbalance approach to determine that un-mined, hydrothermally altered watersheds can contribute as much as 56-90\% of dissolved metal loads to surface waters, but the possible influences of multiple geologic watershed variables on water quality were not assessed.

\section{GIS and statistical approaches used for other study} areas

Previous studies in other areas have utilized watershed-based GIS and statistical approaches to evaluate the influences of watershed physical characteristics on water quality. Wang and Yin (1997) used GIS to assess the effects of variable land use and land cover type on surface water quality. Investigations in subalpine to alpine areas have addressed the influence that terrain slope, vegetation, surficial deposits, and bedrock lithology have on water quality (Clow and Sucker 2000). Sliva and Williams (2001) used analysis of entire watershed area and a linear GIS stream buffer to assess influences of land use types on water quality.

A watershed-based and statistical approach was used in the central Colorado Rocky Mountains by Schmidt et al. 
Fig. 1 Location map of the Animas River watershed study area showing geographic features discussed in text. Shaded areas are RMMD Red Mountain mining district, EMD Eureka mining district, and SSMA South Silverton mining area. Note that E. of Carbon Lakes and Red Tributaries are informal names used to describe features discussed in the text. Red line Silverton caldera structural margin, purple dashed line San Juan caldera southern topographic margin

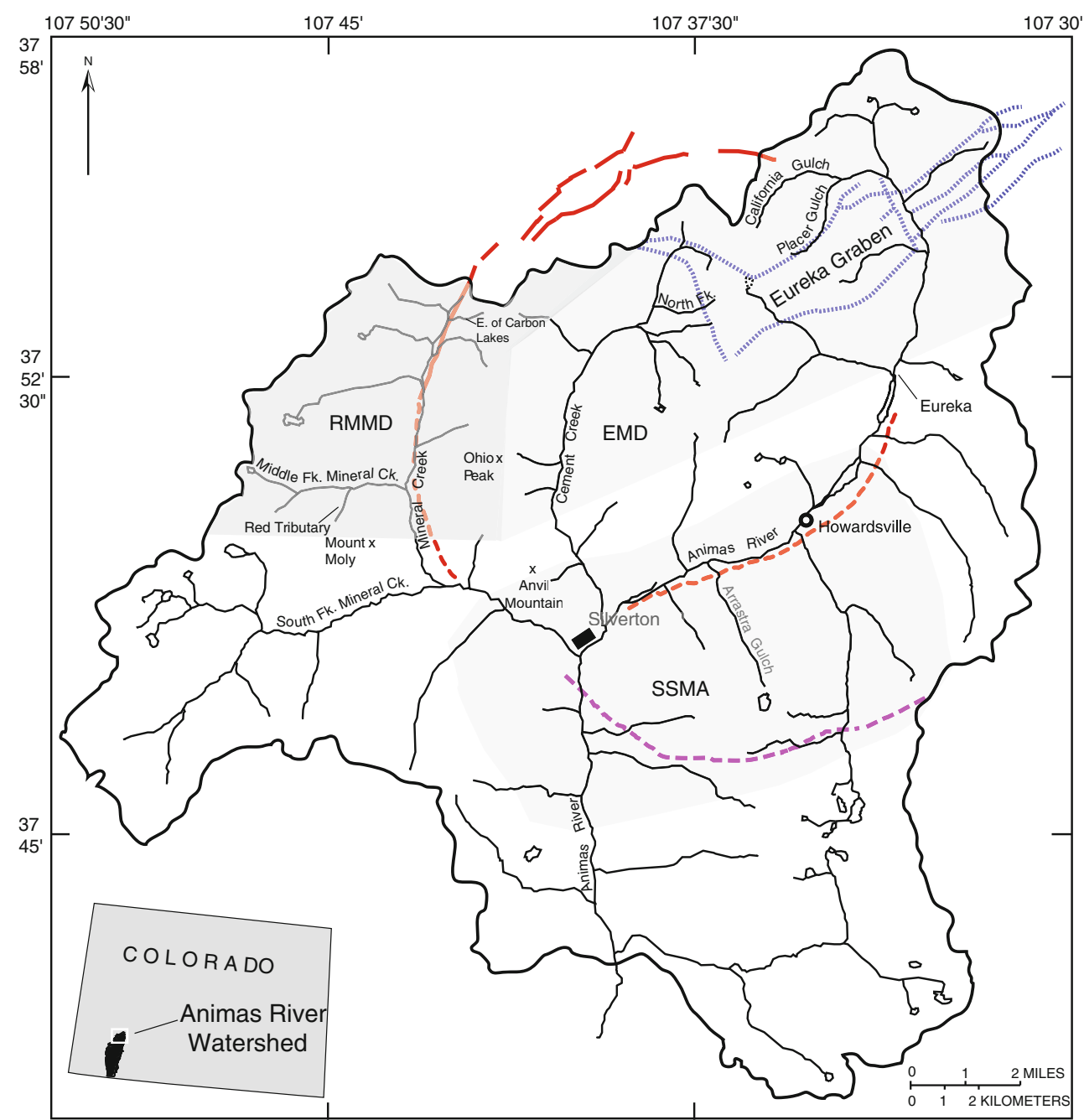

(2009, 2010), which includes GIS analysis of generalized alteration types derived from analysis of advanced spaceborne thermal emission and reflection radiometer (ASTER) data, water quality determined for samples collected at watershed outlets, and macro benthic invertebrate data as an indicator of ecosystem health. Their work identifies inverse correlations between area of hydrothermal alteration and macro benthic taxa type and abundance. An approach similar to that of Schmidt et al. (2009) was used by Bruns (2005), who developed a GIS and statistical analysis methodology of watersheds to understand stream ecosystem response to potential land use impacts caused by coal mining in northeastern Pennsylvania and southern New York.

\section{Methodology and datasets}

Methods used in this study combined a GIS and a statistically based approach that builds on preliminary work
(Yager et al. 2002; Yager and Caine 2003; Yager et al. 2008a, b). In this study, GIS was used to analyze digital terrain surfaces to create derivative watersheds and hydrologic stream networks that, in turn, could be used to analyze AML geology and alteration datasets in a geochemical and geologic context. The watersheds are used as a geographic frame of reference for determining area of geologic units and alteration types.

Work completed as part of this study differs from previous research in that data acquired using GIS analysis of geologic and detailed alteration maps completed during AML investigations (Bove et al. 2007a; Yager and Bove 2007) were used to test statistical correlations between water quality signatures and hydrothermal alteration mapped using three different remote sensing platforms. The remote sensing datasets utilized in this study included: (1) Landsat Thematic Mapper (TM) (Rockwell 2010), (2) ASTER (Rockwell 2010), and (3) Airborne Visible Infrared Imaging Spectrometer (AVIRIS) (Bove et al. 2007a). 
Geomorphometric and GIS methods

A surface hydrologic modeling tool, the GIS Weasel (Viger et al. 1998; Viger and Leavesley 2007; Viger 2008), was used to analyze a $10 \mathrm{~m}$ resolution USGS digital elevation model (DEM) and extract watershed data including slope, aspect, flow direction, flow accumulation, and drainage network grids. Standard DEM preprocessing commands available in $\mathrm{ArcGrid}^{\mathrm{TM}}$ were utilized that are accessed by the GIS Weasel software application. The DEM preprocessing steps (fill, flow direction, and flow accumulation) are required for subsequent geomorphometric analysis because these functions control how hydrologic flow is routed on a digital surface having grid-cell $x-y$ coordinate locations and elevation information. Fill is calculated using a technique described by Jenson and Domingue (1988) that locates each cell whose elevation is lower than that of eight adjacent neighboring cells and raises the elevation of these cells to that of its nearest neighbors. Once erroneous topographic depressions are corrected using Fill, this permits the downhill flow across a DEM to be determined. Flow direction is calculated from the filled DEM, using the D8 algorithm (Jenson and Domingue 1988). The flowdirection surface is then used to calculate a flow accumulation surface, which delineates those higher elevation cells that contribute flow to a specific grid cell (Jenson and Domingue 1988; O'Callaghan and Mark 1984). A hydrologic stream network grid was established using the flow accumulation (flowacc) grid and the following ArcGrid ${ }^{\mathrm{TM}}$ conditional (con) function:

streamnet $=$ con $($ flowacc $>1,000,1)$

A flow accumulation threshold of 1,000 was used in the Streamnet function. All 10-m resolution cells in the flow accumulation grid with more than 1,000 cells flowing into them are assigned 1, and all other cells are assigned no data. The grid-cell contributing area of 1,000 used in this study resulted in a realistic, basin-wide hydrologic network that most closely resembled the drainage network observed in the field.

The GIS Weasel software utilizes the Watershed function of $\mathrm{ArcGrid}^{\mathrm{TM}}$ to delineate watersheds that represent upstream contributing areas derived from a source grid (Viger and Leavesley 2007). Each delineated watershed has a unique numeric identifier that can be associated with attributes of other geodatasets and provides a basis for spatial and statistical comparisons (Fig. 2). Once watersheds were delineated, GIS Weasel parameterization routines were used to calculate areas of alteration and bedrock lithologies in each watershed derived from digital geologic and alteration maps (Yager and Bove 2007; Bove et al. 2007a). In addition, an AVIRIS-derived vegetation map (Dalton et al. 2007) was analyzed using GIS to determine intersections between vegetated and barren areas corresponding with alteration types for each watershed. The zonal statistics function available in $\operatorname{ArcGIS}^{\mathrm{TM}}$ was used to calculate the area of each watershed alteration type derived from the ASTER and TM alteration grids. Tables of watershed alteration types were imported into Mintitab ${ }^{\mathrm{TM}}$ software for statistical analysis.

A 30-m GIS buffer was applied to the hydrologic network grid to determine areas adjacent to streams that intersect alteration types. GIS buffer-derived data were subsequently compiled for statistical comparison with results from whole watershed statistical analysis. GISbuffered areas adjacent to a stream network could represent locations within a watershed that are more susceptible to hydrologic weathering due to sediment being transported along perennial and ephemeral stream channels where the erosive power of surface water runoff may be highest. The GIS stream buffer was only applied to the AVIRIS-based alteration map in which alteration types were extrapolated to include vegetated areas, resulting in nearly complete watershed mineral mapping coverage. The only unmapped parts of the AVIRIS-based alteration map are those areas covered by surficial deposits.

\section{Remote sensing data}

\section{Landsat Thematic Mapper}

TM measures six spectral bands between 0.4 and $2.4 \mu \mathrm{m}$. Bands 1, 2, and 3 overlap the visible, blue, green, and red parts of the electromagnetic spectrum between 0.4 and $0.7 \mu \mathrm{m}$. Bands $4(0.7-0.9 \mu \mathrm{m}), 5(1.5-1.8 \mu \mathrm{m})$, and 7 $(2.0-2.4 \mu \mathrm{m})$ measure in the near- to shortwave infrared (SWIR) parts of the spectrum. Absorption spectra detected by TM are too broad to delineate specific minerals, but the spectra do permit mineral groups such as clays and iron minerals important in hydrothermally altered areas to be mapped. The spatial resolution for TM data is $30 \mathrm{~m}$. In the Animas River study area, only 2-3\% areas above tree-line that are devoid of vegetation are adequately exposed for TM mineral group mapping. TM band ratios are used to reduce the effect of uneven illumination and enhance spectral contrast (Rockwell 2010). A compound ratio of $(5 / 7-4 / 3)$ was used to delineate the clay-sulfate-sericite minerals. The spectral influence of chlorophyll-bearing green vegetation (highlighted by the $4 / 3$ ratio) was removed from the $5 / 7$ ratio results. A compound band ratio of $(3 / 1 \times(3+5 / 4))$ was used to highlight ferric iron minerals having strong charge transfer absorptions in band 1 and crystal field absorptions in band 4 (Fig. 3). TM data are available for the entire United States and are, therefore, pertinent to national-scale geoenvironmetal assessments. 


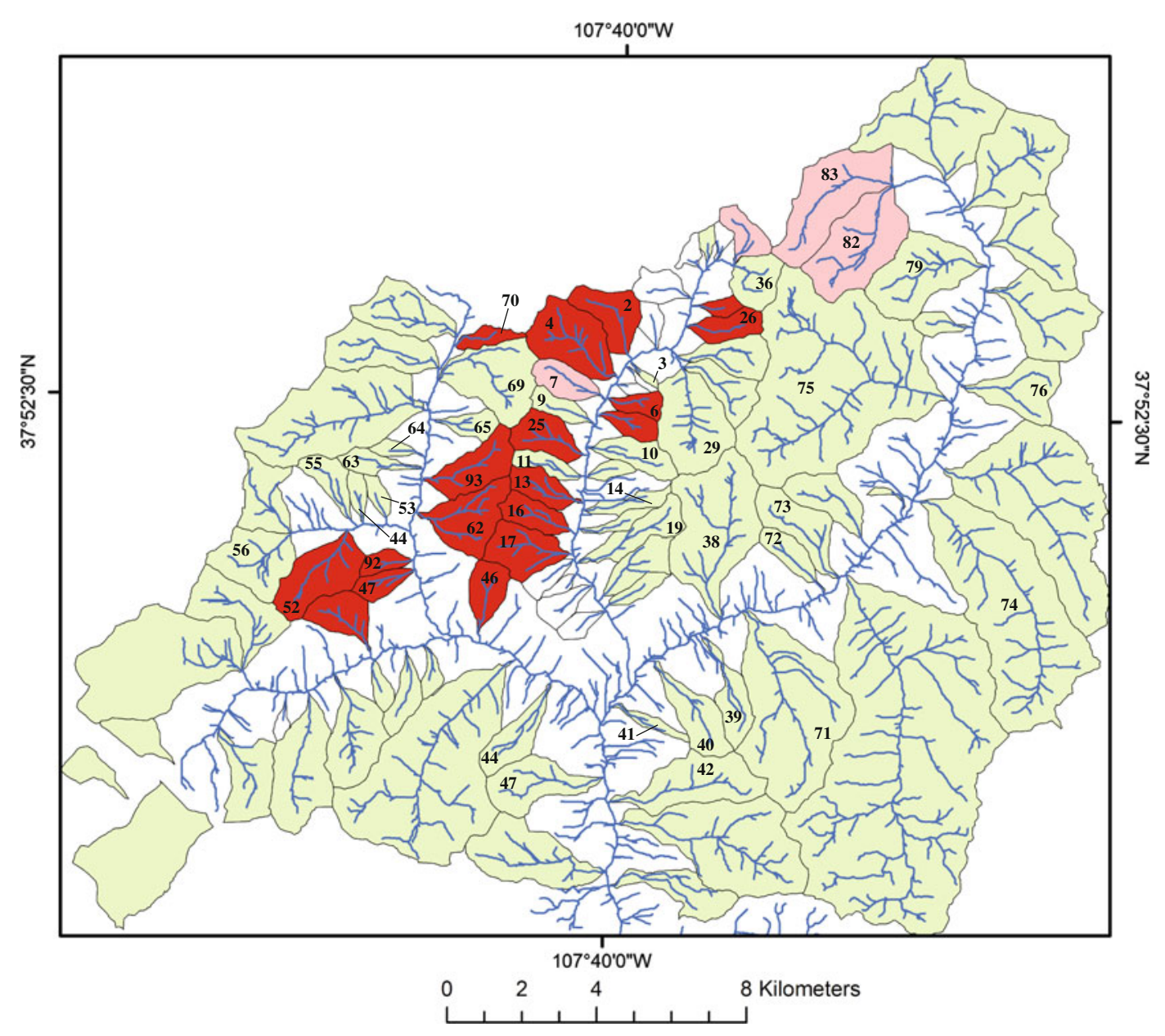

Fig. 2 Watersheds and associated id's delineated using the GIS Weasel software interface and the ArcGridTM watershed function. Watersheds in green (near neutral $\mathrm{pH})$, coral $(5.0-6 \mathrm{pH})$, red $(<5 \mathrm{pH})$. GIS id's are only shown for areas sampled at the watershed outlet or discussed in text. The id's and corresponding names are listed as follows: 2 Dry Gulch, 3 South of Dry Gulch, 4 Prospect Gulch, 6 Tiger Gulch, 7 Georgia Gulch, 9 Fairview Gulch, 10 Cascade Gulch, 11 Porcupine Gulch, 13 Ohio Gulch, 14 Illinois Gulch, 16 Topeka Gulch, 17 Niagra Gulch, 19 Hancock Gulch, 25 Minnesota Gulch, 26 North Fork Cement Creek, 29 South Fork Cement Creek at Gladstone, 36 Ross basin, 38 Boulder Gulch, 39 Blair Gulch, 40 Swansea Gulch,

Alteration types mapped by TM data and area calculations determined by GIS are in Table 1 .

\section{ASTER}

The ASTER sensor measures reflected solar radiation in three bands between 0.52 and $0.86 \mu \mathrm{m}$ and six bands between 1.6 and $2.43 \mu \mathrm{m}$; and emitted radiation in five bands between 8.125 and $11.65 \mu \mathrm{m}$ (ERSDAC 2005). Absorption features in the shortwave infrared spectral region between 1.0 and $2.5 \mu \mathrm{m}$ are shown to be particularly
41 Idaho Gulch, 42 Kendall Gulch, 44 Northeast of Belcher mine, 46 Zuni Gulch, 47 Battle Ship Slide, 52 Red Tributary, 53 Middle Fork Mineral Creek (east watershed), 54 Middle Fork Mineral Creek (central watershed), 55 Middle Fork Mineral Creek (western watershed), 56 Paradise basin, 62 South of Brown's Gulch, 63 South of Imogene Mine, 64 West of Imogene Mine, 65 Southeast of Chattanooga, 69 Big Horn Gulch, 70 Carbon Lake, 71 Arrastra Gulch, 73 Hematite Gulch, 75 Eureka Gulch, 76 Niagra Gulch (upper Animas River basin), 79 Picayune Gulch, 82 Placer Gulch, 83 California Gulch, 87 Cunningham Creek, 92 South of Bonner mine, 93 Brown's Gulch

useful for mapping silicates and carbonates (Hunt and Salisbury 1970, 1971; Rockwell 2009). The spatial resolution for the SWIR part of the spectrum is $30 \mathrm{~m}$. Vegetation cover commonly obscures $88 \%$ of watershed areas in the Animas River study area permitting $12 \%$ of the area to be mapped by ASTER (Fig. 4). Minerals and mineral mixtures were identified from the ASTER data using spectroscopic analysis techniques described by Rockwell (2009). The identified minerals were then combined into alteration and lithologic types using a Boolean modeling technique based on standard definitions of the alteration 


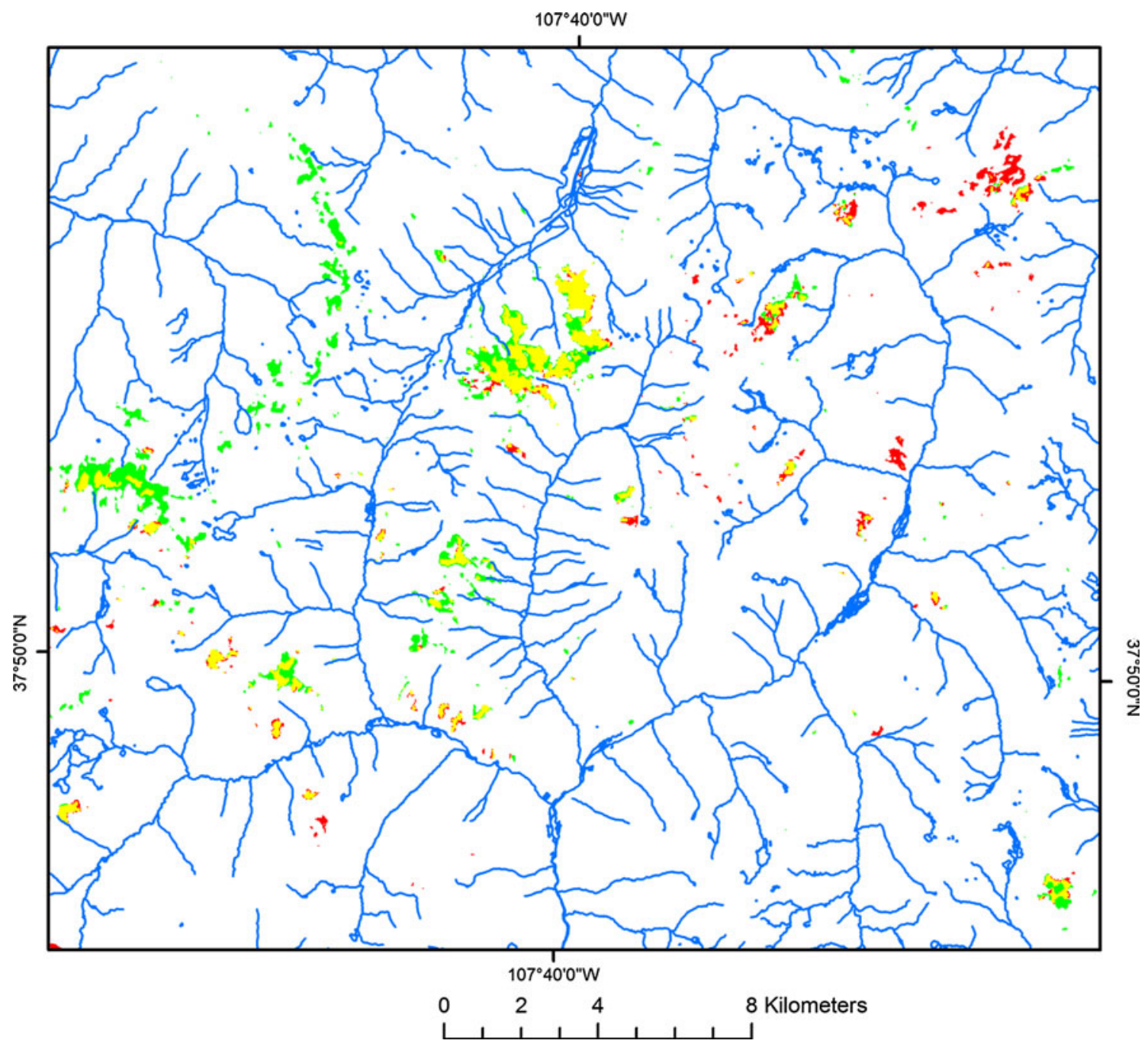

Fig. 3 Distribution of mineral groups identified using ratio-based analysis of TM data. Yellow ferric iron + clay-sulfate-mica, Green claysulfate-mica only, Red ferric iron only

mineralogy (Rockwell 2010). Modeled alteration types include separate argillic, four pyrite-bearing, and six propylitic and carbonate-bearing alteration assemblages. ASTER is available for the entire US and could be a valuable tool for mapping hydrothermal alteration as part of geoenvironmental assessments requiring coverage of large areas. Alteration types mapped by ASTER and area calculations determined by GIS are in Table 1 .

\section{Hybrid AVIRIS and field-based alteration map}

In contrast to TM and ASTER, AVIRIS data are available only in selected areas of the US for detailed study of relatively small watershed areas or specific basins. A hybrid alteration map that integrates AVIRIS spectral interpretations of Dalton et al. (2007) and field-based mapping (Bove et al. 2007a) provides nearly $100 \%$ bedrock coverage irrespective of vegetation cover (Fig. 5). AVIRIS has 224 narrow spectral bands between 0.4 and $2.5 \mu \mathrm{m}$ that are in the visible, near infrared and mid-infrared parts of the spectrum. The narrow spectral bands enable individual minerals to be delineated due to characteristic absorption spectra of mineral species. The AVIRIS spectra used for the hybrid alteration mapping have a spatial resolution of $17 \mathrm{~m}^{2}$ and represent the highest resolution remote sensing dataset used in our analysis. AVIRIS mineral mapping was supplemented by field-based mapping and mineralogy studies augmented by X-ray diffraction analyses, which permitted the entire area of each watershed not covered by surficial deposits to be assigned to one of 21 alteration types (Bove et al. 2007a). This hybrid product contrasts with TM- and ASTER-derived alteration maps in which 
Table 1 Alteration type area $\left(\mathrm{m}^{2}\right)$ determined by GIS analysis of Landsat-TM and ASTER alteration mapping for Cement Creek, Mineral Creek, and upper Animas River basin watersheds

\begin{tabular}{|c|c|c|c|c|c|}
\hline Basin and Wathersheds & $\begin{array}{l}\text { TM-clay- } \\
\text { sulfate-sericite }\end{array}$ & $\mathrm{TM}-\mathrm{Fe}$ & $\begin{array}{l}\text { ASTER argillic } \\
+ \text { ferric Fe }\end{array}$ & $\begin{array}{l}\text { ASTER quartz-sericite- } \\
\text { pyrite (phyllic) }\end{array}$ & $\begin{array}{l}\sum(\text { all ASTER quartz- } \\
\text { sericite-pyrite })\end{array}$ \\
\hline \multicolumn{6}{|l|}{ Cement Creek basin } \\
\hline Dry Gulch & 485,100 & 538,200 & 169,425 & 135,225 & 135,225 \\
\hline South of Dry Gulch & 0 & 0 & 0 & 0 & 0 \\
\hline Prospect Gulch & 361,800 & 633,600 & 166,725 & 165,825 & 165,825 \\
\hline Tiger Gulch & 0 & 4,500 & 1,350 & 1,575 & 1,575 \\
\hline Georgia Gulch & 26,100 & 70,200 & 1,575 & 0 & 225 \\
\hline Fairview Gulch & 0 & 900 & 0 & 0 & 0 \\
\hline Cascade Gulch & 0 & 6,300 & 900 & 675 & 675 \\
\hline Porcupine Gulch & 45,000 & 52,200 & 19,575 & 18,900 & 18,900 \\
\hline Ohio Gulch & 302,400 & 327,600 & 92,250 & 78,975 & 79,875 \\
\hline Illinois Gulch & 0 & 0 & 2,250 & 1,575 & 1,575 \\
\hline Topeka Gulch & 99,900 & 139,500 & 42,750 & 37,800 & 38,025 \\
\hline Niagara Gulch & 81,900 & 134,100 & 49,500 & 75,825 & 75,825 \\
\hline Hancock Gulch & 0 & 1,800 & 225 & 1,350 & 1,350 \\
\hline Minnesota Gulch & 0 & 40,500 & 6,750 & 1,125 & 2,475 \\
\hline South Fork Cement Creek (above M. Fork) & 141,300 & 158,400 & 32,850 & 69,750 & 70,650 \\
\hline North Fork Cement Creek & 29,700 & 98,100 & 5,850 & 17,325 & 17,325 \\
\hline Ross basin & 0 & 16,200 & 0 & 0 & 0 \\
\hline \multicolumn{6}{|l|}{ Mineral Creek basin } \\
\hline Northeast of Belcher Mine & $1,748,700$ & 0 & 450 & 0 & 675 \\
\hline Zuni & $1,351,800$ & 36,900 & 48,375 & 39,600 & 39,825 \\
\hline Battleship slide & 813,600 & 27,000 & 20,250 & 11,250 & 13,500 \\
\hline Red Tributary & $2,673,900$ & 156,600 & 48,600 & 13,050 & 14,625 \\
\hline South of Bonner Mine & 612,900 & 900 & 1,125 & 0 & 0 \\
\hline Middle Fork Mineral Creek-East Basin & 476,100 & 0 & 0 & 0 & 450 \\
\hline Middle Fork Mineral Creek-Central Basin & 492,300 & 7,200 & 0 & 450 & 450 \\
\hline Middle Fork Mineral Creek-West Basin & $1,165,500$ & 34,200 & 6,075 & 2,025 & 2,250 \\
\hline Paradise Basin & $2,814,300$ & 85,500 & 13,275 & 2,025 & 5,175 \\
\hline South of Browns Gulch & $2,406,600$ & 228,600 & 52,425 & 91,800 & 91,800 \\
\hline Browns & $2,124,900$ & 75,600 & 18,675 & 24,975 & 24,975 \\
\hline South of Imogene Mine & 833,400 & 1,800 & 2,475 & 675 & 675 \\
\hline West of Imogene Mine & 409,500 & 0 & 1,575 & 900 & 900 \\
\hline Southeast of Chattanooga & 811,800 & 0 & 1,350 & 1,125 & 1,125 \\
\hline Big Horn Gulch & $3,865,500$ & 15,300 & 10,575 & 0 & 0 \\
\hline East of Carbon Lake & 666,000 & 0 & 2,025 & 1,350 & 1,350 \\
\hline \multicolumn{6}{|l|}{ Upper Animas River basin } \\
\hline Boulder Gulch & 0 & 0 & 3,150 & 900 & 1,350 \\
\hline Arrastra Creek & 900 & 2,700 & 4,725 & 0 & 1,575 \\
\hline Hematite Gulch & 0 & 900 & 0 & 0 & 0 \\
\hline California Gulch & 306,900 & 186,300 & 9,225 & 0 & 1,575 \\
\hline Blair Gulch & 0 & 0 & 0 & 0 & 225 \\
\hline Niagra Gulch (upper Animas) & 4,500 & 17,100 & 675 & 0 & 0 \\
\hline Swansea Gulch & 0 & 900 & 0 & 0 & 0 \\
\hline Eureka Gulch & 98,100 & 254,700 & 9,900 & 0 & 7,200 \\
\hline Picayune Gulch & 0 & 8,100 & 450 & 0 & 0 \\
\hline Placer Gulch & 106,200 & 230,400 & 8,775 & 225 & 1,125 \\
\hline
\end{tabular}




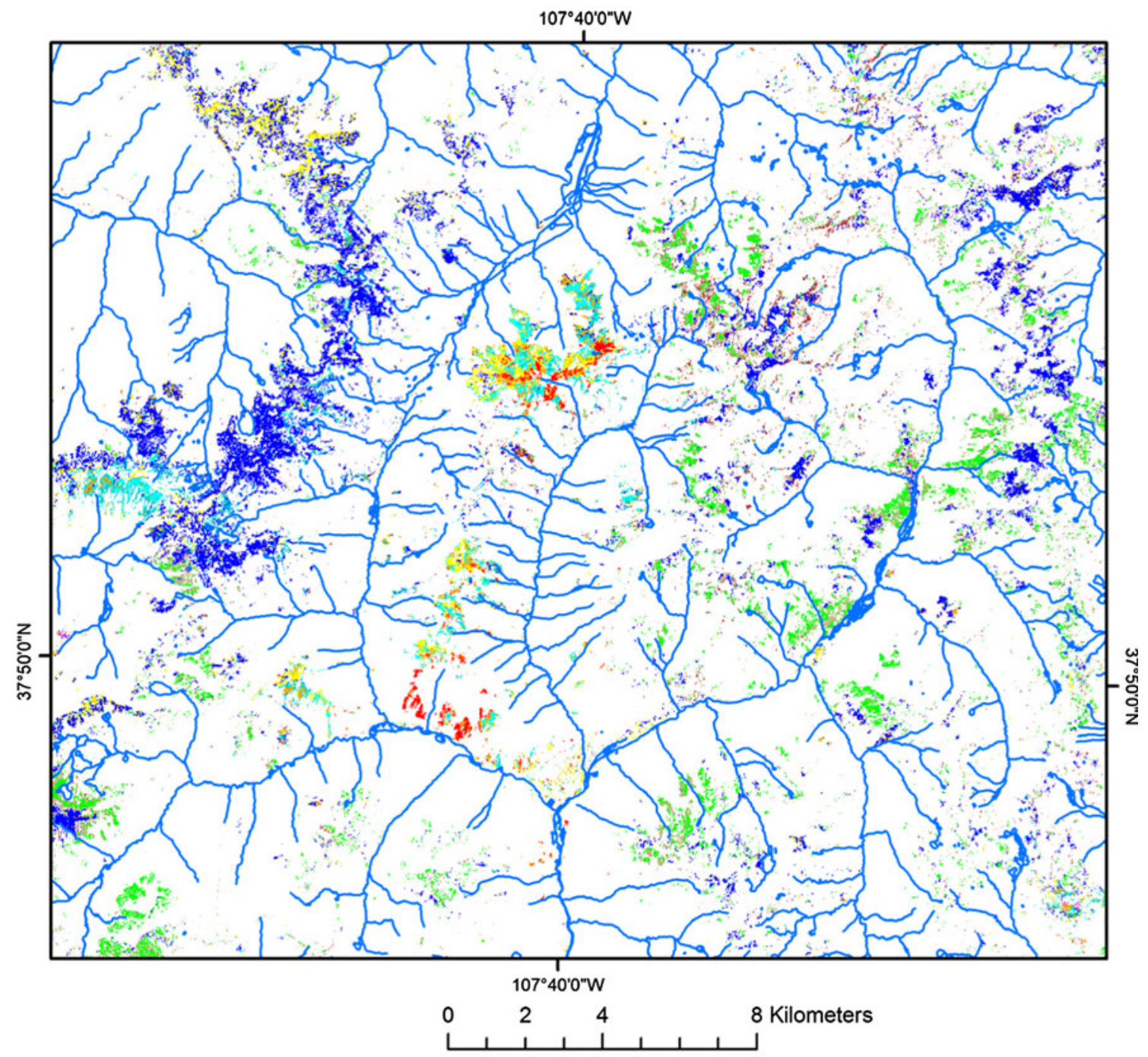

Explanation

Alteration type and key mineral assemblages grouped by relative net acid production and acid neutralizing capacity

High net acid production (NAP)

\begin{tabular}{|c|c|}
\hline & phyllic (QSP) \\
\hline & highly pyritic QSP $+/$ - hydrous silica \\
\hline & pyritic (jarosite) \\
\hline \multicolumn{2}{|c|}{$\begin{array}{l}\text { Moderate to high NAP } \\
\text { (variable pyrite content) }\end{array}$} \\
\hline & advanced argillic \\
\hline & argillic + ferric iron \\
\hline & argillic (or clay-bearing rocks) \\
\hline \multicolumn{2}{|c|}{ Low to moderate NAP } \\
\hline & $\begin{array}{l}\text { regional propylitic to weak QSP - } \\
\text { minor sericite + ferric iron }\end{array}$ \\
\hline
\end{tabular}

$$
\begin{aligned}
& \text { Moderate to high acid neutralizing } \\
& \text { capacity (ANC) } \\
& \text { propylitic + sericite } \\
& + \text { ferric iron } \\
& \text { propylitic + ferric iron } \\
& \text { propylitic + sericite } \\
& \text { regional propylitic - } \\
& \mathrm{Fe} / \mathrm{Mg} \text { sericite +/- chlorite } \\
& \text { High ANC } \\
& \text { propylitic (or carbonate rocks) } \\
& \text { No significant NAP or ANC } \\
& \text { hydrous silica - opal and (or) } \\
& \text { chalcedony }
\end{aligned}
$$

Fig. 4 Distribution of alteration mapped by ASTER that was used in GIS alteration area determinations

vegetated areas are not shown. Hydrothermally altered areas mapped with AVIRIS, however, show excellent correlation with those altered areas mapped by $\mathrm{TM}$ and
ASTER (Rockwell 2010). Alteration from hybrid AVIRISderived map and area calculations determined by GIS are in Table 2. 


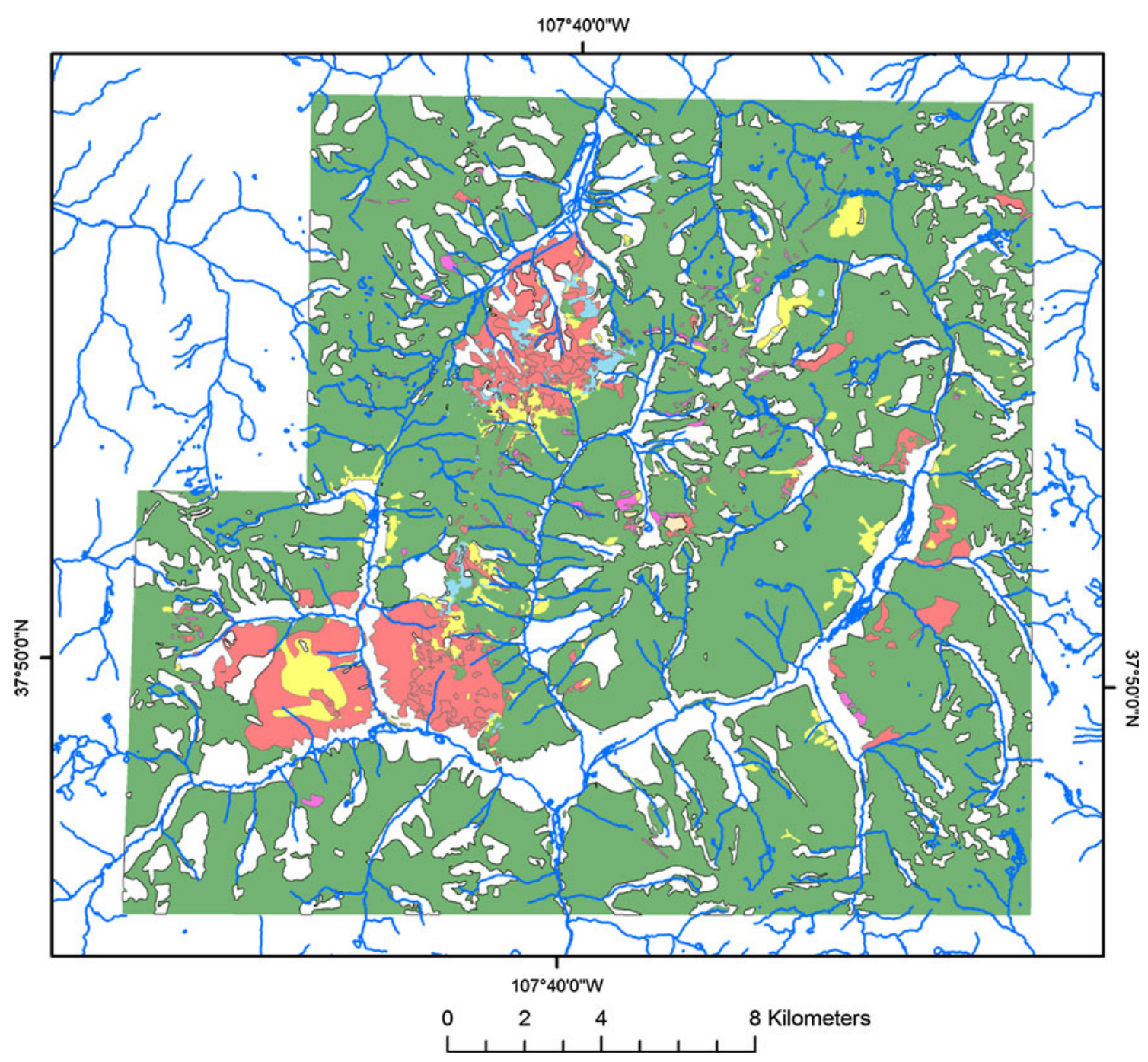

Fig. 5 Hybrid AVIRIS- and field-based map of alteration. Prevalent areas in green are propylitically altered rocks. Brighter hues represent more intense alteration that has overprinted the propylitic assemblage. A detailed geologic map (Yager et al. Yager and Bove 2007) is available for download at http://pubs.usgs.gov/pp/1651/downloads/; an alteration map is described in Bove et al. (Bove et al. 2007a, 2007) and available online at http://pubs.usgs.gov/sim/2976/

\section{Statistical methods}

\section{Linear regression analysis}

Linear regression was used to test correlations between watershed variables (alteration type, terrain, and vegetation) and water quality signatures. The Kendall's tau coefficient was used to measure the statistical dependence between two measured quantities - for example, the area of a specific alteration type and $\mathrm{pH}$ or metal concentration. Kendall's tau is a non-parametric and statistically robust method, meaning that it does not make assumptions about a continuous probability distribution, e.g., that the data are normally distributed. The method also uses a correlation coefficient that measures the correspondence between two rankings to assess the probability that a resultant correlation is not due to chance (Kendall 1975; Helsel and Hirsch 2002). The significance or robustness of linear dependence between two measured variables is determined using the Kendall-Theil Robust Line, which determines whether a linear regression slope coefficient for the explanatory variable is significantly different from zero (Theil 1950; Helsel and Hirsch 2002). This statistical approach tests whether variables are negatively or positively correlated, or whether there is no statistical relationship between variables. Correlation measures the co-variation between independent variables and dependent water quality parameters; however, the reasons for correlations are determined from knowledge regarding the geology and geologic processes affecting the area. 
Table 2 Alteration type area $\left(\mathrm{m}^{2}\right)$ determined by GIS analysis of hybrid AVIRIS mineral mapping for Cement Creek, Mineral Creek, and upper Animas River basin watersheds

\begin{tabular}{|c|c|c|c|c|c|c|c|c|}
\hline Basin and Watersheds & Total area & Prop & Prop area $(\%)$ & Argillic & qsp & qap & $\sum(\mathrm{NAP})$ & $\begin{array}{l}\text { NAP } \\
\text { area }(\%)\end{array}$ \\
\hline \multicolumn{9}{|l|}{ Cement Creek basin } \\
\hline Dry Gulch & $1,980,400$ & 658,600 & 33 & 114,000 & 241,300 & 296,600 & 930,675 & 47 \\
\hline South of Dry Gulch & 131,600 & 128,100 & 97 & 0 & 0 & 0 & 191 & 0 \\
\hline Prospect Gulch & $3,295,000$ & $1,449,600$ & 44 & 80,200 & 983,800 & 286,100 & $1,394,301$ & 42 \\
\hline Tiger Gulch & 700,100 & 623,000 & 89 & 0 & 0 & 0 & 171 & 0 \\
\hline Georgia Gulch & $1,304,300$ & $1,058,400$ & 81 & 0 & 9,000 & 7,400 & 17,538 & 1 \\
\hline Fairview Gulch & 819,300 & 798,100 & 97 & 0 & 0 & 0 & 2,371 & 0 \\
\hline Cascade Gulch & $1,471,900$ & 931,700 & 63 & 0 & 0 & 0 & 86,930 & 6 \\
\hline Porcupine Gulch & 793,500 & 477,500 & 60 & 19,700 & 92,500 & 19,100 & 117,929 & 15 \\
\hline Ohio Gulch & $1,244,900$ & 483,900 & 39 & 71,900 & 280,200 & 104,300 & 427,589 & 34 \\
\hline Illinois Gulch & 784,500 & 725,900 & 93 & 0 & 0 & 0 & 91,677 & 12 \\
\hline Topeka Gulch & $1,291,300$ & 894,300 & 69 & 112,000 & 221,400 & 52,800 & 274,334 & 21 \\
\hline Niagara Gulch & $2,185,300$ & 720,900 & 33 & 19,200 & 422,800 & 184,700 & 688,804 & 32 \\
\hline Hancock Gulch & $1,797,300$ & 902,900 & 50 & 0 & 0 & 0 & 929 & 0 \\
\hline Minnesota Gulch & $1,678,200$ & $1,505,600$ & 90 & 0 & 0 & 0 & 3,963 & 0 \\
\hline South Fork Cement Creek (above M. Fork) & $4,157,900$ & $2,389,500$ & 57 & 0 & 0 & 0 & 87,713 & 2 \\
\hline North Fork Cement Creek & $1,198,700$ & 730,800 & 61 & 0 & 0 & 0 & 112 & 0 \\
\hline Ross basin & $1,605,500$ & $1,149,600$ & 72 & 0 & 0 & 0 & 72,828 & 5 \\
\hline \multicolumn{9}{|l|}{ Mineral Creek basin } \\
\hline Northeast of Belcher Mine & $1,752,000$ & $1,154,100$ & 66 & 0 & 0 & 0 & $1,034,500$ & 0 \\
\hline Zuni Gulch & $1,378,300$ & 46,900 & 3 & 700 & 18,100 & 122,500 & 288,100 & 21 \\
\hline Battleship Slide & 827,300 & 0 & 0 & 0 & 521,600 & 0 & 797,900 & 96 \\
\hline Red Tributary & $3,045,600$ & 398,800 & 13 & 0 & 371,300 & 0 & $1,773,400$ & 58 \\
\hline South of Bonner Mine & 616,000 & 0 & 0 & 0 & 148,600 & 0 & 556,700 & 90 \\
\hline Middle Fork Mineral Creek-East Basin & 478,400 & 410,700 & 86 & 0 & 0 & 0 & 59,200 & 12 \\
\hline Middle Fork Mineral Creek-Central Basin & 493,800 & 358,200 & 72 & 0 & 0 & 0 & 119,000 & 24 \\
\hline Middle Fork Mineral Creek-West Basin & $1,170,300$ & 761,000 & 65 & 0 & 0 & 0 & 2,100 & 0 \\
\hline Paradise Basin & $2,995,400$ & $1,220,000$ & 41 & 0 & 0 & 0 & $1,651,400$ & 55 \\
\hline South of Browns Gulch & $2,721,800$ & 357,800 & 13 & 164,900 & 156,400 & 69,100 & 619,800 & 23 \\
\hline Browns Gulch & $2,267,300$ & $1,232,500$ & 54 & 63,400 & 38,800 & 1,500 & 115,000 & 5 \\
\hline South of Imogene Mine & 834,400 & 484,400 & 58 & 0 & 0 & 0 & 0 & 0 \\
\hline West of Imogene Mine & $2,267,300$ & $1,232,500$ & 93 & 63,400 & 38,800 & 1,500 & 115,000 & 5 \\
\hline Southeast of Chattanooga & 834,400 & 484,400 & 95 & 0 & 0 & 0 & 0 & 0 \\
\hline Big Horn Gulch & 402,900 & 376,500 & 98 & 0 & 13,800 & 0 & 13,800 & 3 \\
\hline East of Carbon Lake & 816,600 & 773,500 & 95 & 0 & 19,700 & 0 & 19,700 & 2 \\
\hline \multicolumn{9}{|l|}{ Mineral Creek basin } \\
\hline Boulder Gulch & $6,770,200$ & $5,592,700$ & 83 & 0 & 0 & 0 & 0 & 0 \\
\hline Arrastra Creek & $10,387,000$ & $7,888,200$ & 76 & 0 & 0 & 0 & 107,500 & 1 \\
\hline Hematite Gulch & $2,380,700$ & $2,352,600$ & 99 & 0 & 0 & 0 & 0 & 0 \\
\hline California Gulch & $4,968,700$ & $3,251,800$ & 65 & 6,300 & 297,600 & 0 & 486,200 & 10 \\
\hline Blair Gulch & $1,563,000$ & 914,500 & 58 & 0 & 0 & 0 & 0 & 0 \\
\hline Niagra Gulch (upper Animas) & $2,518,900$ & $1,624,800$ & 64 & 0 & 0 & 0 & 45,000 & 2 \\
\hline Swansea Gulch & $2,130,500$ & $1,053,100$ & 49 & 0 & 0 & 0 & 65,900 & 3 \\
\hline Eureka Gulch & $19,357,000$ & $15,235,600$ & 79 & 0 & 0 & 0 & 278,500 & 1 \\
\hline Picayune Gulch & $4,181,000$ & $3,413,400$ & 82 & 0 & 0 & 0 & 1,000 & 0 \\
\hline Placer Gulch & 480,470 & $3,326,900$ & 69 & 28,800 & 142,200 & 0 & 622,100 & 13 \\
\hline
\end{tabular}




\section{Factor analysis}

Factor analysis was completed on the remote sensing alteration datasets derived from TM, ASTER, and AVIRIS data, and associated watershed water quality parameters. Factor analysis was used to help identify distinct patterns of occurrence and relationships among multiple variables that could synergistically affect watershed surface water quality. The principal component analysis extraction method was applied to the datasets, which seeks a linear combination of variables such that the maximum variance is extracted from the variables. The maximum variance is removed and analysis proceeds iteratively until the desired number of factors is extracted. This method seeks the fewest factors that can explain the variance (correlation) of a set of variables. Factor loadings $(1-n)$ are the correlation coefficients between variables (rows) and factors (columns). Rotated factor loading scores were used that enable groups of interrelated data to be determined. The squared factor loading is the percent of variance in that indicator variable explained by the factor and is equivalent to Pearson's $r$ (Helsel and Hirsch 2002).

\section{Water quality data}

Watershed and GIS-buffered area characteristics compiled using GIS were statistically evaluated to determine correlations between watershed physical properties and associated water quality signatures. Water quality analyses used for statistical comparisons were determined for samples collected at watershed outlets during synoptic sampling events (Table 3). A watershed outlet is defined as the lowest elevation location that can be sampled prior to surface water entering a main stem stream. The water quality determined at a watershed outlet represents a geochemical integration of all upstream water-rocksoil-sediment-atmosphere interactions and processes (Fig. 6).

The primary source of water quality data used in this analysis is from a relational database described in Sole and Rich (2007) and was populated from data collected as part of AML investigations (Mast et al. 2000a, 2007; Leib et al. 2007; Kimball et al. 2007; Wright et al. 2007). Samples collected during base-flow conditions during late summer to fall, primarily between 1996 and 2002, were used for analysis. Water quality samples collected during base flow conditions have element concentrations that are relatively unaffected by snowmelt dilution and are thought to closely represent groundwater discharge to streams.

\section{Results}

GIS-derived statistics for primary rock units

GIS was used to analyze AML geodatasets to determine area of bedrock units, alteration types, and vegetation coverage for each watershed. The study area consists of $63 \%$ igneous bedrock terrain. Paleozoic, Mesozoic, and Tertiary sedimentary rock units represent $6 \%$ of the study area. Precambrian crystalline bedrock exposed primarily along the southern caldera margins represent $4 \%$ of outcrops. Extensive, quaternary sedimentary deposits cover $26 \%$ of the study area and range in thickness from a few meters to more than $30 \mathrm{~m}$ (Yager et al. 2000; Johnson and Yager 2006; Johnson 2007).

The most widespread igneous rock type is the Silverton Volcanics intermediate composition lavas and volcaniclastic units that form $52 \%$ of the igneous rocks and that are host to $90 \%$ of metallic mineral deposits (Bejnar 1957). Silverton Volcanics lava filled the area of subsidence caused by San Juan caldera collapse (Yager and Bove 2002, 2007). Intermediate composition volcaniclastic deposits and minor lava flows of the San Juan Formation, exposed primarily outside the Silverton and San Juan caldera margins, represent $28 \%$ of the igneous rocks and are the second-most abundant igneous unit. Granitoid intrusive rocks of the Sultan Mountain Stock are preserved along the western and southern caldera structural margins and comprise $8 \%$ of the igneous rock units. The rhyolite to dacite composition Eureka Member of the Sapinero Mesa Tuff, derived from the San Juan caldera, represents $6 \%$ of the igneous rock units and is exposed along the southern caldera margins and along the Eureka graben.

\section{GIS-derived statistics for alteration types}

During AML investigations, AVIRIS- and field-based mineral mapping permitted 21 acid-generating alteration types to be identified (Bove et al. 2007a). GIS-derived area determinations from the AVIRIS data for the principal, acid-generating alteration types determined in the Bove et al. (2007a) study are listed in order of decreasing area and are as follows: (1) propylitic acid sulfate (prop-as: $22 \%$ ); (2) quartz-sericite-pyrite (qsp: $17 \%$ ); (3) weak sericitepyrite-hydrothermal (wsp-hyd: $17 \%$ ); (4) quartz-alunitepyrophyllite (qap: $6 \%$ ); (5) weak sericite-pyrite-propylitic (wsp-prop: 6\%); (6) Quaternary quartz-alunite-sericite (Qqas: $6 \%$ ); (7) mixed quartz-alunite and quartz-alunitepyrophyllite (qap-s: $5 \%$ ); (8) weak sericite-pyrite (wsp: $4 \%$ ), and (9) argillic (arg: $4 \%$ ) (Table 1, ESM only). For a detailed discussion of the alteration types listed above the reader is referred to Bove et al. (2007a). 
Table 3 Water quality parameters for samples collected at watershed outlets in the Upper Animas River, Cement Creek, and Mineral Creek basins during base-flow conditions

\begin{tabular}{|c|c|c|c|c|c|c|c|c|c|}
\hline Basin and Watershed & Date & $\mathrm{pH}$ & $\mathrm{SpC}$ & $\mathrm{Al}$ & $\mathrm{Fe}$ & $\mathrm{Cu}$ & $\mathrm{Zn}$ & $\mathrm{SO}_{4}$ & Alkalinity \\
\hline \multicolumn{10}{|l|}{ Cement Creek basin } \\
\hline Dry Gulch & 09/26/97 & 3.89 & 89 & 907 & 155 & 36 & 91 & 22 & N.A. \\
\hline South of Dry Gulch & 09/20/1996 & 5.74 & 841 & 2,030 & 4,450 & 35 & 888 & 400 & N.A. \\
\hline Prospect Gulch & 09/08/1997 & 3.22 & 526 & 11,500 & 26,800 & 136 & 1,130 & 227 & N.A. \\
\hline Tiger Gulch & 09/20/1996 & 3.23 & 1,410 & 5,540 & 15,500 & 1 & 583 & 667 & 0.1 \\
\hline Georgia Gulch & 09/25/1997 & 5.86 & 205 & 43 & 55 & 10 & 424 & 95 & 1.4 \\
\hline Fairview Gulch & 09/26/1997 & 7.5 & 113 & 40 & 30 & 4 & 20 & 30 & 27.5 \\
\hline Cascade Gulch & 09/04/1997 & 7.96 & 243 & 40 & 30 & 4 & 20 & 82 & 29 \\
\hline Porcupine Gulch & 09/29/1997 & 6.38 & 655 & 86 & 3,200 & 4 & 930 & 325 & 11.1 \\
\hline Ohio Gulch & 09/20/1996 & 3.04 & 980 & 11,200 & 25,300 & 161 & 1,040 & 356 & 0.1 \\
\hline Illinois Gulch & 09/04/1997 & 7.91 & 162 & 40 & 30 & 4 & 20 & 45 & 29 \\
\hline Topeka Gulch & 09/20/1996 & 4.88 & 1,090 & 4,160 & 4,270 & 28 & 198 & 597 & 10 \\
\hline Niagara Gulch & 9/28/1997 & 3.51 & 247 & 2,930 & 2,040 & 20 & 93 & 65 & N.A. \\
\hline Hancock Gulch & 9/20/1996 & 7.32 & 195 & 42 & 27 & 3 & 38 & 29 & 92 \\
\hline Minnesota Gulch & $9 / 20 / 1996$ & 4.19 & 353 & 1,830 & 1,210 & 66 & 408 & 176 & 0.1 \\
\hline $\begin{array}{l}\text { South Fork Cement } \\
\text { Creek (at Gladstone) }\end{array}$ & 08/17/1999 & 6.34 & 344 & 196 & 998 & 10 & 366 & 147 & 1 \\
\hline $\begin{array}{l}\text { North Fork Cement } \\
\text { Creek }\end{array}$ & 09/07/91 & 3.1 & 353 & 8,400 & 16,000 & 1,400 & 4,200 & N.A. & N.A. \\
\hline Ross basin & 09/10/1997 & 6.17 & 199 & 109 & 10 & 66 & 1,200 & 90 & 2.1 \\
\hline \multicolumn{10}{|l|}{ Mineral Creek basin } \\
\hline $\begin{array}{l}\text { Northeast of Belcher } \\
\text { Mine }\end{array}$ & 09/13/1999 & 7.10 & 185 & 15 & 5 & 1 & 211 & 59 & 22 \\
\hline Zuni Gulch & 08/25/1999 & 3.90 & 48 & 315 & 99 & 19 & 20 & 10 & N.A. \\
\hline Battle Ship Slide & 09/15/1999 & 3.79 & 220 & 3,850 & 2,840 & 75 & 127 & 70 & 0.01 \\
\hline Red Tributary & $10 / 02 / 1998$ & 3.32 & 1,410 & 54,000 & 69,300 & 21 & 354 & 780 & \\
\hline South of Bonner Mine & 09/03/1998 & 3.45 & 471 & 2,820 & 2,210 & 13 & 90 & 171 & N.A. \\
\hline $\begin{array}{l}\text { Middle Fork Mineral } \\
\text { Creek-East Basin }\end{array}$ & 09/19/1995 & 6.78 & 180 & 1 & 1 & 2 & 5 & 68 & 17 \\
\hline $\begin{array}{l}\text { Middle Fork Mineral } \\
\text { Creek-Central Basin }\end{array}$ & 09/14/1995 & 6.56 & 106 & 1 & 1 & 1 & 1 & 25 & 23 \\
\hline $\begin{array}{l}\text { Middle Fork Mineral } \\
\text { Creek-West Basin }\end{array}$ & 09/20/1995 & 8.02 & 143 & 30 & 1 & 1 & 1 & 28 & 39 \\
\hline Paradise Basin & 08/27/1998 & 6.86 & 566 & 100 & 310 & 4 & 52 & 263 & 9.5 \\
\hline South of Browns Gulch & 08/25/1999 & 3.25 & 311 & 5,510 & 2,160 & 78 & 38 & 98 & \\
\hline Browns Gulch & 07/18/1999 & 4.3 & 270 & 4,110 & 376 & 53 & 940 & 138 & N.A. \\
\hline South of Imogene Mine & 09/15/1999 & 6.86 & 210 & 18 & 5 & 7 & 258 & 70.3 & 24.8 \\
\hline West of Imogene Mine & 09/15/1999 & 7.44 & 182 & 30 & 5 & 8 & 34 & 73.2 & N.A. \\
\hline $\begin{array}{l}\text { Southeast of } \\
\text { Chattanooga }\end{array}$ & 09/15/1999 & 6.51 & 314 & 230 & 35 & 10 & 143 & 130 & N.A. \\
\hline Big Horn Gulch & 09/17/1999 & 6.92 & 125 & 80 & 214 & 24 & 317 & 31.50 & 22 \\
\hline East of Carbon Lake & 09/17/1999 & 3.54 & 304 & 1,250 & 6,860 & 2,630 & 3,590 & 102 & 0.01 \\
\hline \multicolumn{10}{|l|}{$\begin{array}{l}\text { Upper Animas River } \\
\text { basin }\end{array}$} \\
\hline Boulder Gulch & 9/26/1997 & 7.45 & 93 & 63 & 10 & 4 & 25 & 22 & 21.5 \\
\hline Arrastra Creek & 9/14/1997 & 7.92 & 184 & 41 & 7 & 3 & 147 & 44 & 41.5 \\
\hline Hematite Gulch & 9/23/1998 & 8.24 & 277 & 55 & 30 & 4 & 20 & 81 & 59 \\
\hline California Gulch & 8/18/1998 & 5.32 & 278 & 1,800 & 113 & 8 & 1,440 & 117 & 4 \\
\hline Blair Gulch & 9/14/1997 & 7.52 & 673 & 30 & 10 & 1 & 776 & 360 & 50 \\
\hline Niagra Gulch & 9/09/1988 & 7.27 & 195 & 40 & 30 & 4 & 20 & 61 & 35 \\
\hline Swansea Gulch & 9/10/1991 & 6.9 & 92 & N.A. & 24 & N.A. & 76 & N.A. & N.A. \\
\hline Eureka Gulch & 9/14/1998 & 7.1 & 308 & 140 & 30 & 6 & 373 & 117 & 22 \\
\hline Picayune Gulch & 9/09/1998 & 6.86 & 386 & 62 & 30 & 4 & 20 & 127 & 69 \\
\hline Placer Gulch & 9/28/1998 & 5.93 & 195 & 362 & 704 & 21 & 1,210 & 78 & 3 \\
\hline Idaho Gulch & $6 / 25 / 1992$ & 8.10 & N.A. & 20 & 15 & 9 & 50 & N.A. & N.A. \\
\hline Kendall Gulch & 8/17/1998 & 7.82 & 129 & 15 & 5 & 8 & 8 & 12 & N.A. \\
\hline
\end{tabular}

Values in italics are $1 / 2$ detection limit

Red OFR-00-53, blue USGS Professional Paper 1651 database (2007), green Unpublished Report to Water Quality Control Commission, Animas River Stakeholders Group, 2001 Placer gulch sample UA33 is downstream of Evening Star Mine (mid-basin). SpC specific conductance 


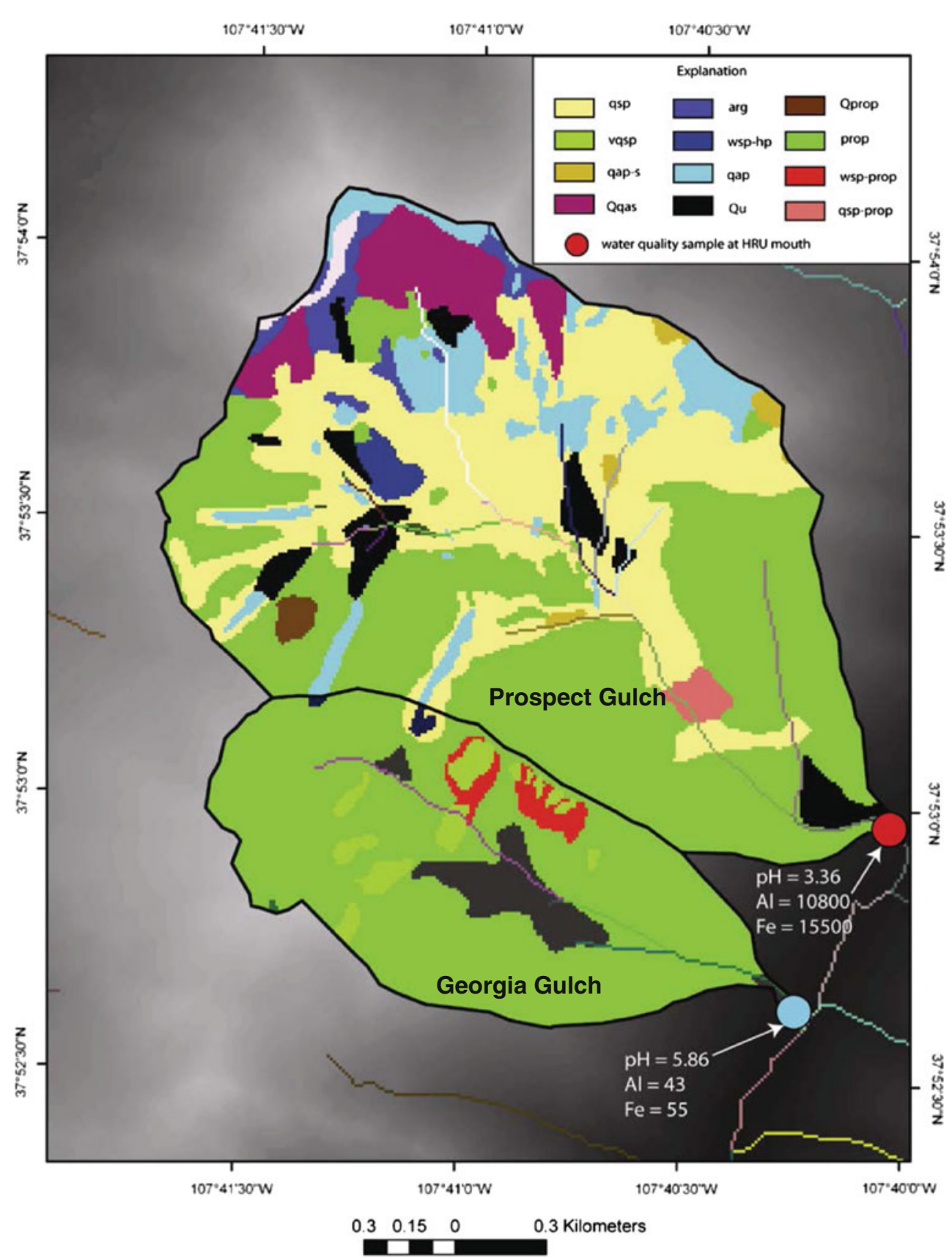

Fig. 6 Example of water quality samples collected at watershed outlets; parameters $\mathrm{pH}, \mathrm{Al}$, and $\mathrm{Fe}$ concentration shown for comparison. Watersheds have greatly differing proportions of alteration types with Georgia Gulch having much less acidic conditions due to the presence of abundant propylitic rocks (green), and lower $\mathrm{Al}$ and $\mathrm{Fe}$ concentrations compared to Prospect Gulch. Detailed descriptions of alteration types in Bove et al. (2007a)

NAP alteration. The NAP area determined for 17 acidic watersheds with $\mathrm{pH}<5.5$ ranges from 2.4 to $96.0 \%$ with a mean NAP area of $46 \%$. Acidic watersheds having small areas of NAP alteration are commonly impacted by mining features such as draining adits. For example, GIS analysis of North Fork Cement Creek and East of Carbon Lakes watersheds with highly acidic water quality lacked significant NAP alteration and thus by inference could be 
identified as being mining impacted (Table 2). In contrast, the NAP area for 29 watersheds with $\mathrm{pH}>5.5$ ranges from 0 to $24 \%$ with a mean NAP area of only $4.1 \%$. Note that alteration assemblages containing mixtures of NAP and ANC, e.g., qsp-prop are included in the NAP area determinations. This is because the propylitic component may be insufficient to neutralize acidity attributed to weathering of the qsp component having NAP > ANC.

The Mineral Creek, Cement Creek, and upper Animas River basins have varying proportions of NAP rocks that are associated with multiple types of hydrothermal systems. The Mineral Creek basin in the western part of the study area is associated with (1) a low-grade $\mathrm{Cu}-\mathrm{Mo}$ porphyry system that formed between South and Middle Forks of Mineral Creek and (2) with acid sulfate alteration centered on Ohio Peak-Anvil Mountain (OPAM) to the east (Bove et al. 2007a). Alteration associated with the $\mathrm{Cu}-\mathrm{Mo}$ porphyry and acid sulfate systems is extensive with some watersheds in these areas being entirely and intensely altered. The Upper Cement Creek basin has significant areas of acid sulfate alteration within the Red Mountain mining district and is also impacted by alteration in the OPAM area that forms the drainage divide between Mineral and Cement Creek basins. Smaller areas of NAP alteration occur along vein structures of the Eureka graben. Alteration in the upper Animas River basin east of Silverton is mainly associated with calderarelated vein structures that formed in the South Silverton mining area and along the Eureka graben in California and Placer Gulch's (Varnes 1963; Casadevall and Ohmoto 1977).

Fig. 7 Intensely altered propylitic rocks (red and yellow) in the Red Mountain mining district, overprinting the regional, propylitically altered igneous rocks (grayish-green), peaks at top of image. View to west
Areas and watershed elevation of ANC rocks and effect on $\mathrm{pH}$

Propylitic alteration containing abundant secondary ANC minerals (calcite, chlorite, epidote) is pervasive, overprinting most of the igneous sequence (Burbank 1960; Bove et al. 2007a). Propylitic alteration was mapped in $67 \%$ of the study area. Regionally, extensive propylitic alteration is preserved where it is not overprinted by more intense hydrothermal alteration having NAP and affecting $9 \%$ of the study area (Fig. 7; Table 4).

GIS calculations were used to determine the percent area and mean elevation of propylitic rocks in each watershed. If propylitic rocks are exposed in a watershed at a high elevation relative to the mean watershed elevation, weathering of these rocks could produce surface water with initial alkalinity that might mitigate acidity caused by weathering of NAP alteration or mining areas exposed at lower elevations. The percent area of propylitic rocks was also calculated for watersheds having greater and less than pH 5.5 at watershed outlets (Table 5). A pH of 5.5, similar to that of rainwater, was used as a gage for acidic versus less acidic water quality. Watersheds with less acidic to neutral water quality $(\mathrm{pH}>5.5)$ have an average of $74 \%$ propylitic area (Fig. 8). Only three of the less acidic to neutral watersheds (Big Horn, Placer, and Porcupine watersheds) have a mean elevation of propylitic rocks that is lower than the mean watershed elevation. In contrast, acidic watersheds average $44 \%$ propylitic area and $64 \%$ of those watersheds have a mean propylitic rock elevation that occurs below the watershed mean elevation (Fig. 8).

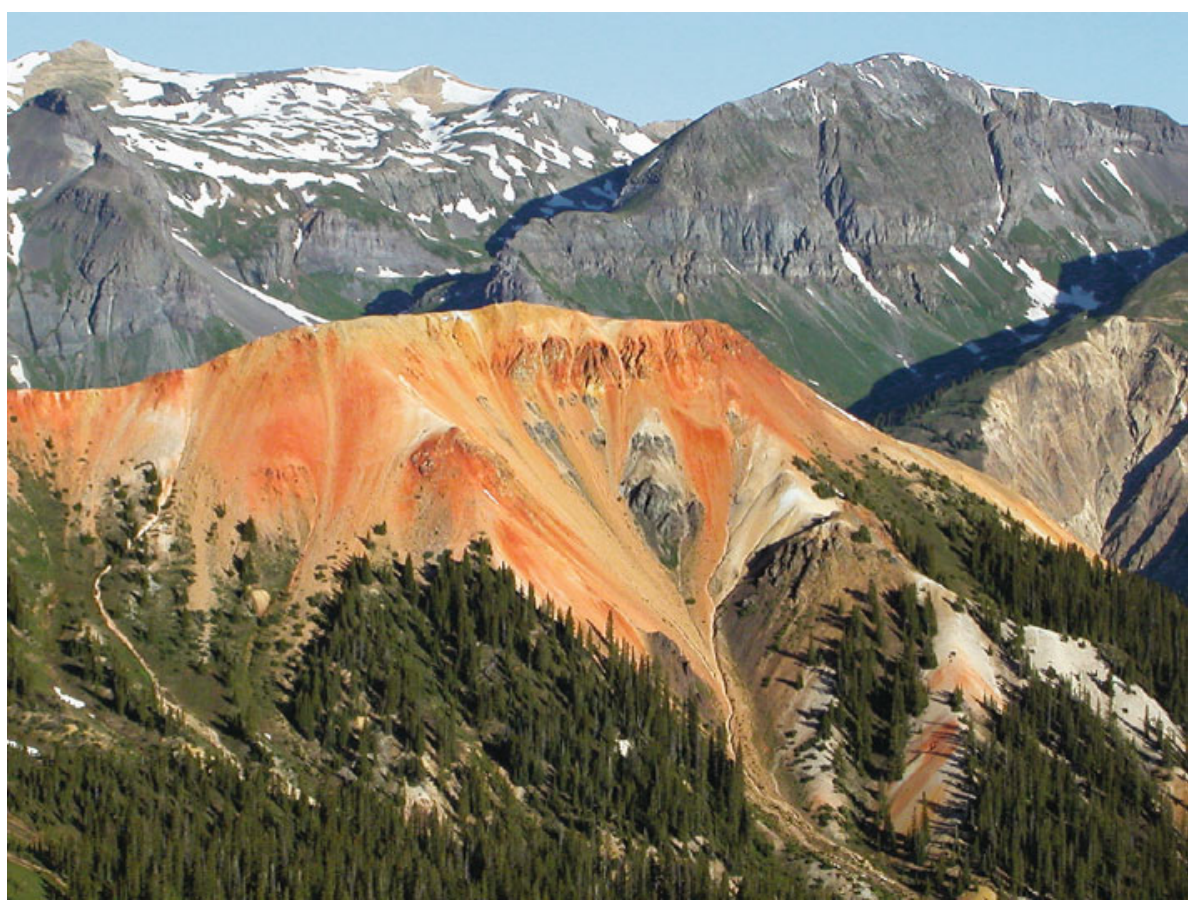


Table 4 Summary statistics determined by GIS for generalized propylitic rocks and net acid producing assemblages for (A) whole study area, and major basins; (B) watersheds that comprise each basin

\begin{tabular}{|c|c|c|c|}
\hline & $\begin{array}{l}\text { Propylitic } \\
\text { area }(\%)\end{array}$ & $\begin{array}{l}\text { Net acid } \\
\text { producing } \\
\text { rocks }(\%)\end{array}$ & $\mathrm{pH}$ \\
\hline \multicolumn{4}{|l|}{ A } \\
\hline $\begin{array}{l}\text { Generalized alteration groups } \\
\text { (whole watershed) }\end{array}$ & 67 & 9 & 5.82 \\
\hline \multicolumn{4}{|c|}{ Generalized alteration types for basins } \\
\hline Upper Animas River basin & 77 & 3 & 7.12 \\
\hline Cement Creek basin & 62 & 20 & 3.56 \\
\hline Mineral Creek basin & 51 & 30 & 6.29 \\
\hline \multicolumn{4}{|l|}{ B } \\
\hline \multicolumn{4}{|c|}{$\begin{array}{l}\text { Generalized alteration groups summary statistics for watersheds } \\
\text { analyzed in each basin }\end{array}$} \\
\hline Upper Animas River & 72 & 3 & \\
\hline Cement Creek basin & 66 & 13 & \\
\hline Mineral Creek basin & 53 & 25 & \\
\hline
\end{tabular}

pH was determined on September 8, 2009 at hydrologic gage stations; whole study area $\mathrm{pH}$ represented by water quality sample collected near gage A72 below Silverton, Colorado

Mining impacts can overwhelm the ANC properties of propylitically altered rocks. For example, Mineral and Cement Creek basins have acidic surface water quality with Cement Creek being more acidic, despite Cement Creek basin having $11 \%$ greater area of propylitic rocks (Table 4). Cement Creek is heavily impacted by mining compared with the less heavily mined Mineral Creek basin, and this could explain the lower $\mathrm{pH}$ of Cement Creek. In contrast to the more highly altered Mineral and Cement Creek basins, the upper Animas River basin on the western margin of the study area has low acidity, an average of $77 \%$ propylitic rocks and only $3 \%$ NAP rocks. The upper Animas River basin water sampled near the basin outlet upstream from Cement Creek has a near neutral $\mathrm{pH}$ (Table 4).

\section{Vegetated and non-vegetated areas}

Vegetated and non-vegetated areas were delineated using GIS analysis of AVIRIS-derived maps (Dalton et al. 2007). Alteration and vegetation layers were overlain to determine non-vegetated areas that intersect hydrothermally altered rock. Non-vegetated areas enhance the potential for erosion because plants are unavailable for interception of precipitation. Lack of interception by plants enhances splash detachment, an important physical weathering mechanism (Kinnell 2005). Intensely altered areas lacking vegetation tend to have more highly acidic water quality compared with vegetated areas. Acidic watersheds have an average of nearly $13 \%$ non-vegetated areas that intersect NAP alteration. In contrast, less acidic to neutral watersheds $(\mathrm{pH}>5.5)$ have an average of $2 \%$ non-vegetated areas that coincide with NAP alteration.

Morphometric parameters determined by GIS

The principal morphometric parameters that were statistically analyzed in relation to water quality signatures were basin area, stream length, and drainage density (Table 2, ESM only). These parameters are very similar for Mineral and Cement Creek basins. Upper Animas River basin watersheds are $26 \%$ larger, have average stream lengths that are 32-37\% longer, and drainage densities that are nearly $8 \%$ greater compared to Mineral and Cement Creek basins.

Slope and aspect were also considered to be potentially important morphometric parameters. Topographic relief in the study area is high and average watershed slopes are consistently steep with a gradient commonly $>25^{\circ}$. This resulted in the slope showing no significant correlation with water quality. Additional data are needed to fully evaluate the role that aspect may play in influencing water quality. This is because aspect strongly controls the timing of snow melt runoff and thus influences when infiltration of surface water into soils and bedrock and subsequent weathering reactions occur. Southerly facing slopes, for example, experience earlier melting compared to northerly slopes, and snow lasts longer throughout a season on north facing slopes. To permit interpretations regarding potential effect on water quality signatures, data acquisition is required at different times during a hydrologic cycle for watersheds with similar proportions of alteration and with varying aspect.

Linear regression analysis of alteration data

\section{TM data}

Linear regression coefficients were determined for alteration assemblages mapped by analysis of TM data and water quality parameters for the combined, mined and unmined watersheds, and separately for watersheds having minimal mining impacts (Table 6). Despite only 2-3\% watershed areas being mapped by TM due to vegetation cover, statistically significant correlations were determined between TM-derived alteration types and water quality signatures. Negative correlations are observed between area of clay-sulfate-sericite ${ }^{1}$ alteration (TM-CSM), $\mathrm{pH}$,

\footnotetext{
${ }^{1}$ It is emphasized here that the TM-CSM is not mapping marble in the study area, but marble is permissive in this TM grouping defined by Rockwell (2010). The principal mineral groups mapped in hydrothermally altered areas include clays, sulfate (alunite), and sericite.
} 
Table 5 Mean watershed elevation, mean elevation of propylitic rocks, total area of propylitic rocks, and $\mathrm{pH}$ for each watershed

Bold indicates elevation of propylitic rocks is higher than the mean watershed elevation, italics are watersheds with nearly equal mean elevation and propylitic mean elevation, nonitalics and non-bold indicates mean elevation of propylitic rocks is lower than mean elevation

\begin{tabular}{|c|c|c|c|c|}
\hline Watershed & $\begin{array}{l}\text { Mean watershed } \\
\text { elevation }(m)\end{array}$ & $\begin{array}{l}\text { Mean elevation of } \\
\text { propylitic rocks (m) }\end{array}$ & $\begin{array}{l}\text { Pr propylitic } \\
\text { rock area }(\%)\end{array}$ & $\mathrm{pH}$ \\
\hline Ohio Gulch & 3,407 & 3,318 & 39 & 3.04 \\
\hline North Fork Cement & 3,669 & 3,690 & 61 & 3.10 \\
\hline Prospect Gulch & 3,551 & 3,503 & 44 & 3.22 \\
\hline Tiger Gulch & 3,489 & 3,483 & 89 & 3.23 \\
\hline South of Browns Gulch & 3,474 & 3,395 & 13 & 3.25 \\
\hline Red Tributary & 3,524 & 3,576 & 13 & 3.32 \\
\hline South of Bonner & 3,321 & No propylitic & 0 & 3.45 \\
\hline Niagra, Cement Creek Basin & 3,441 & 3,300 & 33 & 3.51 \\
\hline East of Carbon Lake & 3,517 & 3,516 & 95 & 3.54 \\
\hline Battleship Slide & 3,395 & No propylitic & 0 & 3.79 \\
\hline Dry Gulch & 3,562 & 3,451 & 33 & 3.89 \\
\hline Zuni Gulch & 3,461 & 3,641 & 3 & 3.9 \\
\hline Minnesota & 3,497 & 3,501 & 90 & 4.19 \\
\hline Browns Gulch & 3,527 & 3,592 & 54 & 4.3 \\
\hline Topeka Gulch & 3,401 & 3,370 & 69 & 4.88 \\
\hline California Gulch & 3,758 & 3,736 & 65 & 5.32 \\
\hline South of Dry & 3,453 & 3,459 & 97 & 5.74 \\
\hline Georgia & 3,557 & 3,566 & 81 & 5.86 \\
\hline Placer & 3,764 & 3,756 & 69 & 5.93 \\
\hline Ross & 3,806 & 3,824 & 72 & 6.17 \\
\hline South Fork Cement & 3,605 & 3,660 & 57 & 6.34 \\
\hline Porcupine & 3,459 & 3,407 & 60 & 6.38 \\
\hline S.E. of Chattanooga & 3,579 & 3,592 & 95 & 6.51 \\
\hline Middle Fork Central & 3,504 & 3,585 & 72 & 6.56 \\
\hline Middle Fork East & 3,437 & 3,471 & 86 & 6.78 \\
\hline South of Imogene & 3,629 & 3,639 & 58 & 6.86 \\
\hline Paradise basin & 3,639 & 3,714 & 41 & 6.86 \\
\hline Picayune Gulch & 3,700 & 3,727 & 82 & 6.86 \\
\hline Swansea & 3,545 & 3,625 & 49 & 6.90 \\
\hline Big Horn & 3,612 & 3,609 & 98 & 6.92 \\
\hline N.E. of Belcher & 3,512 & 3,515 & 66 & 7.10 \\
\hline Eureka & 3,664 & 3,697 & 79 & 7.10 \\
\hline Niagra, Animas River Basin & 3,826 & 3,830 & 64 & 7.27 \\
\hline Hancock & 3,567 & 3,743 & 50 & 7.32 \\
\hline W. of Imogene & 3,467 & 3,488 & 93 & 7.44 \\
\hline Boulder & 3,668 & 3,685 & 83 & 7.45 \\
\hline Fairview & 3,575 & 3,583 & 97 & 7.50 \\
\hline Blair & 3,551 & 3,636 & 58 & 7.52 \\
\hline Illinois & 3,555 & 3,583 & 97 & 7.50 \\
\hline Arrastra & 3,595 & 3,697 & 76 & 7.92 \\
\hline Cascade & 3,613 & 3,623 & 63 & 7.96 \\
\hline Middle Fork West & 3,663 & 3,683 & 65 & 8.02 \\
\hline Hematite & 3,678 & 3,686 & 99 & 8.24 \\
\hline
\end{tabular}

Unmined watersheds were analyzed separately to determine if correlations exist when mining impacts are excluded. Mining impacts, especially draining mine adits 
Fig. 8 Propylitic alteration area (\% of total watershed area) versus $\mathrm{pH}$. Acidic watersheds average $44 \%$ propylitic rock; less acidic to near neutral watersheds average $74 \%$ propylitic rock. Mining impacted watersheds are clearly delineated by watersheds having abundant propylitic rock, yet having low $\mathrm{pH}$

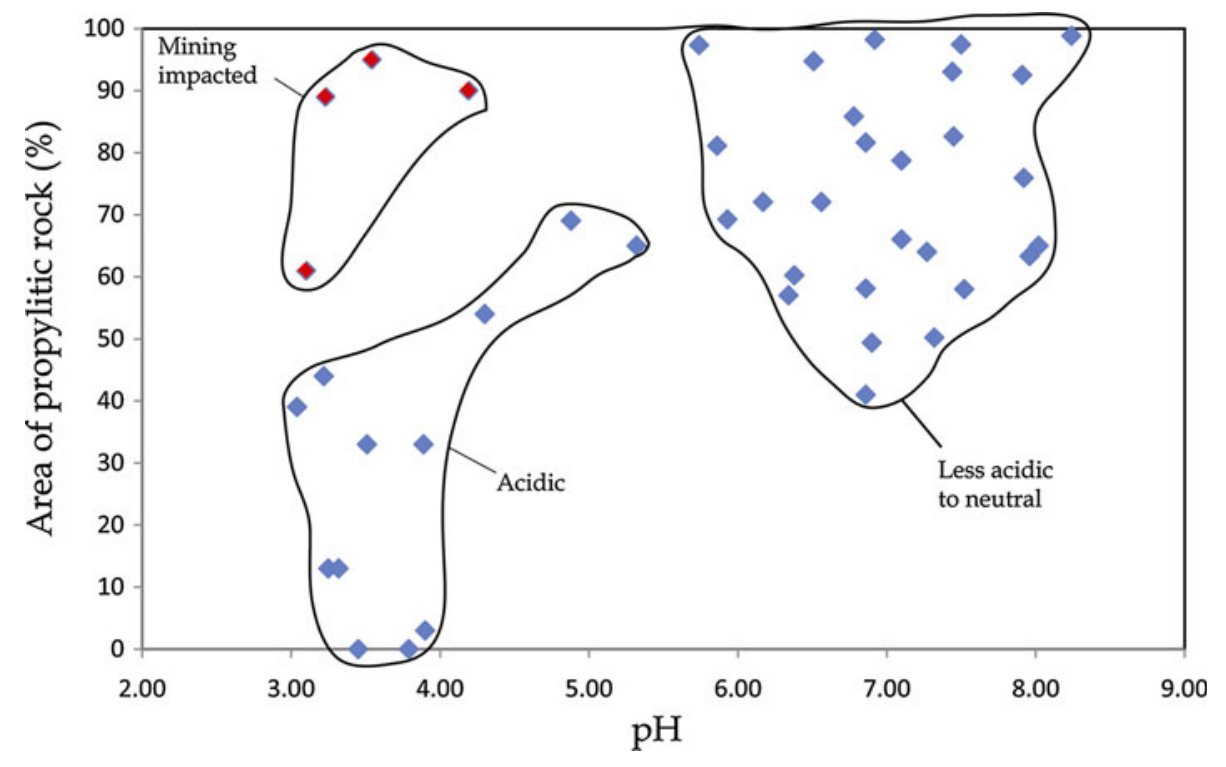

that are observed at several mining areas in Colorado, can adversely impact water quality and complicate interpretation of the geochemical background signal attributed to natural weathering processes of hydrothermally altered areas (Yager et al. 2010). In general, an increase in correlation values was observed when mined watersheds were excluded from regression analysis (Table 7). TM-CSM showed significant trends with $\mathrm{pH}, \mathrm{Fe}$ (which were not observed in the combined mined and unmined dataset), $\mathrm{Al}$, and alkalinity. Correlation values between $\mathrm{TM}-\mathrm{Fe}, \mathrm{pH}, \mathrm{Fe}$, $\mathrm{Al}$, and $\mathrm{Cu}$ also increased. Alkalinity had a lower, negative correlation value compared with the combined mined and unmined dataset.

\section{ASTER data}

Alteration types mapped by ASTER and area calculations determined by GIS and used in statistical analysis are in Table 6. Two alteration assemblages, argillic plus ferric iron (Aster-Arg-Fe) and quartz-sericite-pyrite-phyllic (Aster-qsp), were observed to have correlations with water quality parameters. All argillic and qsp alteration types were also separately summed and statistically analyzed to evaluate the cumulative effect that the $\sum$ all NAP assemblages have on water quality.

Aster-Arg-Fe is negatively correlated with $\mathrm{pH}$ and alkalinity. The major metal cations $\mathrm{Fe}, \mathrm{Al}$, and the trace metal $\mathrm{Cu}$ are positively correlated with area of AsterArg-Fe alteration, with aluminum having the the highest correlation. Analysis of the $\sum$ all argillic alteration assemblages showed a similar trend compared to the Aster-Arg-Fe data, but had a slightly lower negative correlation with alkalinity. Area of Aster-qsp alteration is negatively correlated with $\mathrm{pH}$ and positively correlated with $\mathrm{Fe}, \mathrm{Al}$, and $\mathrm{Cu}$. Correlation values are higher for the $\sum$ all qsp-bearing assemblages and the elements $\mathrm{Fe}, \mathrm{Al}$, and $\mathrm{Cu}$, when compared to correlations obtained with the Aster-qsp alteration assemblage. The "propylitic or carbonate rock" assemblage is not significantly correlated with any water quality parameter.

Correlation values were generally higher for area of Aster-Arg-Fe and water quality parameters when mined watersheds were excluded from analysis (Table 7). This is especially true for $\mathrm{pH}, \mathrm{Fe}, \mathrm{Al}$, and $\mathrm{Cu}$; however, the negative correlation value for alkalinity observed in the combined mined and unmined dataset decreased for the unmined dataset. Correlations also increased for area of Aster-qsp and water quality parameters $\mathrm{pH}, \mathrm{Fe}$, and $\mathrm{Al}$ when mined watersheds were excluded. Correlation values for the $\sum$ all qsp alteration assemblages in ummined watersheds yielded a lower correlation value with $\mathrm{pH}$ and a positive correlation with $\mathrm{Fe}, \mathrm{Al}$, and $\mathrm{Cu}$ that are similar compared to the dataset that includes both mined and unmined watersheds. The propylitic or carbonate rock assemblage showed no statistically significant trends with water quality parameters when mined catchments were excluded.

\section{Hybrid AVIRIS and field mapping data}

Significant correlation values are observed for three acidgenerating alteration types (arg, qsp, and qap) mapped by hybrid AVIRIS- and field-based data (Table 6). In addition, correlations are observed between the $\sum$ all NAP, the ratio $\sum$ propylitic: $\sum$ all NAP, and water quality. Aluminum is positively correlated with area of argillic alteration. No additional water quality parameters are correlated with argillic alteration. Quartz-sericite-pyrite has a relatively high negative correlation with $\mathrm{pH}$, and positive correlation 
Table 6 Linear regression coefficients for area of alteration types determined using TM, ASTER, hybrid AVIRIS and field mapping data, and water quality parameters for combined mined and unmined watersheds

\begin{tabular}{|c|c|c|c|c|c|c|c|c|}
\hline Alteration type & $\mathrm{pH}$ & $\mathrm{Fe}$ & Al & $\mathrm{Cu}$ & $\mathrm{Zn}$ & $\mathrm{SO}_{4}$ & Alkalinity & $\begin{array}{l}\text { Specific } \\
\text { conductance }\end{array}$ \\
\hline \multicolumn{9}{|l|}{$\mathrm{TM}$} \\
\hline \multirow[t]{3}{*}{ Clay-sulfate-sericite alteration } & -0.32 & 0.27 & 0.41 & 0.19 & 0.11 & 0.29 & -0.56 & \\
\hline & $(0.03)$ & $(0.05)$ & $(0.005)$ & $(0.19)$ & $(0.45)$ & $(0.05)$ & $(0.02)$ & \\
\hline & $N=24$ & $N=24$ & $N=24$ & $N=25$ & $N=24$ & $N=24$ & $N=12$ & \\
\hline \multirow[t]{3}{*}{ Iron alteration } & -0.38 & 0.38 & 0.43 & $\mathbf{0 . 3 8}$ & 0.35 & 0.29 & -0.51 & \\
\hline & $(0.0001)$ & $(0.001)$ & 0.0004 & $(0.002)$ & $(0.45)$ & $(0.004)$ & $(0.002)$ & \\
\hline & $N=34$ & $N=33$ & $N=33$ & $N=32$ & $N=24$ & $N=33$ & $N=20$ & \\
\hline \multicolumn{9}{|l|}{ ASTER } \\
\hline \multirow[t]{3}{*}{$\sum$ of all argillic alteration } & -0.37 & 0.41 & 0.47 & 0.39 & 0.16 & 0.07 & -0.32 & \\
\hline & $(0.0009)$ & $(0.0002)$ & $(0.00003)$ & $(0.0004)$ & $(0.14)$ & $(0.51)$ & $(0.03)$ & \\
\hline & $N=38$ & $N=37$ & $N=39$ & $N=37$ & $N=38$ & $N=38$ & $N=23$ & \\
\hline \multirow[t]{3}{*}{ Argillic plus ferric iron alteration } & -0.38 & 0.39 & 0.44 & 0.41 & 0.15 & 0.14 & -0.46 & \\
\hline & $(0.001)$ & $(0.0009)$ & 0.0002 & $(0.0005)$ & $(0.19)$ & $(0.23)$ & $(0.006)$ & \\
\hline & $N=35$ & $N=35$ & $N=35$ & $N=35$ & $N=35$ & $N=35$ & $N=19$ & \\
\hline \multirow[t]{3}{*}{ Quartz-sericite-pyrite (phyllic) } & -0.42 & $\mathbf{0 . 3 9}$ & 0.45 & 0.32 & 0.18 & 0.16 & -0.18 & \\
\hline & $(0.002)$ & $(0.004)$ & $(0.0009)$ & $(0.01)$ & $(0.2)$ & $(0.27)$ & $(0.44)$ & \\
\hline & $N=27$ & $N=26$ & $N=28$ & $N=27$ & $N=27$ & $N=26$ & $N=12$ & \\
\hline \multirow[t]{3}{*}{ Eof all Quartz-sericite-pyrite alteration } & -0.41 & 0.47 & 0.55 & 0.42 & 0.12 & 0.15 & -0.16 & \\
\hline & $(0.0006)$ & $(0.00007)$ & $(0.000005)$ & $(0.00004)$ & $(0.3)$ & $(0.22)$ & $(0.34)$ & \\
\hline & $N=34$ & $N=32$ & $N=33$ & $N=34$ & $N=34$ & $N=33$ & $N=19$ & \\
\hline \multirow[t]{3}{*}{ Propylitic or carbonate rocks } & 0.24 & -0.17 & -0.08 & -0.28 & 0.01 & 0 & 0.06 & \\
\hline & $(0.07)$ & $(0.2)$ & $(0.57)$ & $(0.03)$ & $(0.9)$ & (1) & $(0.71)$ & \\
\hline & $N=28$ & $N=27$ & $N=28$ & $N=28$ & $N=28$ & $N=27$ & $N=21$ & \\
\hline \multicolumn{9}{|l|}{ AVIRIS } \\
\hline \multirow[t]{3}{*}{ Argillic alteration } & -0.25 & 0.28 & 0.46 & 0.31 & -0.23 & 0.31 & -0.04 & 0.28 \\
\hline & $(0.24)$ & $(0.28)$ & $(0.03)$ & $(0.16)$ & $(0.29)$ & $(0.16)$ & (1) & 0.20 \\
\hline & $N=13$ & $N=13$ & $N=13$ & $N=13$ & $N=13$ & $N=13$ & $N=7$ & $N=13$ \\
\hline \multirow[t]{3}{*}{ Quartz-sericite-pyrite alteration } & -0.52 & 0.52 & 0.62 & 0.34 & 0.18 & 0.23 & -0.43 & 0.29 \\
\hline & $(0.003)$ & $(0.003)$ & 0.0003 & $(0.05)$ & $(0.32)$ & $(0.1)$ & $(0.17)$ & 0.09 \\
\hline & $N=18$ & $N=18$ & $N=18$ & $N=18$ & $N=18$ & $N=18$ & $N=8$ & $N=18$ \\
\hline \multirow[t]{3}{*}{ Quartz-alunite-pyropylitic alteration } & -0.49 & 0.15 & 0.36 & 0.12 & 0.21 & 0.06 & -0.33 & 0.06 \\
\hline & $(0.003)$ & $(0.54)$ & $(0.11)$ & $(0.63)$ & $(0.37)$ & $(0.83)$ & $(0.45)$ & 0.84 \\
\hline & $N=12$ & $N=12$ & $N=12$ & $N=12$ & $N=12$ & $N=12$ & $N=6$ & $N=12$ \\
\hline \multirow[t]{3}{*}{$\sum$ of NAP alteration } & -0.41 & 0.29 & 0.39 & 0.19 & 0.14 & 0.28 & -0.28 & 0.30 \\
\hline & $(0.002)$ & $(0.03)$ & $(0.004)$ & $(0.16)$ & $(0.28)$ & $(0.04)$ & (0.09) & 0.02 \\
\hline & $N=28$ & $N=28$ & $N=28$ & $N=28$ & $N=28$ & $N=28$ & $N=19$ & $N=28$ \\
\hline \multirow{3}{*}{$\begin{array}{l}\sum \text { of propylitic alteration: } \sum \text { NAP alteration } \\
\text { (ratio) }\end{array}$} & 0.46 & -0.29 & -0.38 & -0.18 & 0.02 & -0.16 & 0.44 & -0.19 \\
\hline & $(0.0009)$ & $(0.03)$ & (0.009) & $(0.20)$ & $(0.88)$ & $(0.26)$ & $(0.09)$ & 0.17 \\
\hline & $N=26$ & $N=26$ & $N=26$ & $N=25$ & $N=26$ & $N=25$ & $N=18$ & $N=26$ \\
\hline
\end{tabular}

Values in bold indicate statistical trends

$P$ values are in parenthesis, $N$ is number of watersheds used in analyses

with Fe and Al. A possible positive trend is observed between qsp and $\mathrm{Cu}$. Quartz-alunite-pyrophyllite is negatively correlated with $\mathrm{pH}$, but lacks additional correlations with other water quality parameters. The $\sum$ all NAP alteration is negatively correlated with $\mathrm{pH}$, positively correlated with $\mathrm{Al}$, and yields weaker positive trends with $\mathrm{Fe}$, specific conductance, and $\mathrm{SO}_{4}$. A positive trend is also observed for the ratio $\sum$ propylitc: $\sum$ all NAP and $\mathrm{pH}$.

Selected morphometric parameters are correlative with the area of propylitically altered bedrock. A positive 
Table 7 Linear regression coefficients for area of alteration types determined using TM, ASTER and hybrid AVIRIS and field mapping data and water quality parameters for unmined watersheds

\begin{tabular}{|c|c|c|c|c|c|c|c|c|}
\hline Remote sensing platform and alteration type & $\mathrm{pH}$ & $\mathrm{Fe}$ & $\mathrm{Al}$ & $\mathrm{Cu}$ & $\mathrm{Zn}$ & $\mathrm{SO}_{4}$ & Alkalinity & $\begin{array}{l}\text { Specific } \\
\text { conductance }\end{array}$ \\
\hline \multicolumn{9}{|l|}{$\mathrm{TM}$} \\
\hline \multirow[t]{3}{*}{ Clay-sulfate-sericite alteration } & -0.47 & 0.47 & 0.46 & 0.33 & 0.05 & 0.22 & -0.62 & \\
\hline & $(0.02)$ & $(0.02)$ & $(0.02)$ & $(0.09)$ & $(0.8)$ & $(0.27)$ & $(0.07)$ & \\
\hline & $N=15$ & $N=15$ & $N=15$ & $N=15$ & $N=15$ & $N=15$ & $N=7$ & \\
\hline \multirow[t]{3}{*}{ Iron alteration (unmined) } & -0.57 & 0.51 & 0.52 & 0.45 & 0.25 & 0.22 & -0.45 & \\
\hline & $(0.0002)$ & $(0.0009)$ & $(0.0009)$ & $(0.004)$ & $(0.11)$ & $(0.16)$ & $(0.03)$ & \\
\hline & $N=22$ & $N=21$ & $N=21$ & $N=20$ & $N=21$ & $N=21$ & $N=14$ & \\
\hline \multicolumn{9}{|l|}{ ASTER } \\
\hline \multirow[t]{3}{*}{$\sum$ of all argillic alteration } & -0.43 & 0.47 & 0.58 & 0.45 & 0.25 & -0.02 & -0.26 & \\
\hline & $(0.002)$ & $(0.0006)$ & $(0.00003)$ & $(0.0008)$ & $(0.06)$ & $(0.89)$ & $(0.15)$ & \\
\hline & $N=26$ & $N=25$ & $N=26$ & $N=25$ & $N=25$ & $N=26$ & $N=17$ & \\
\hline \multirow[t]{3}{*}{ Argillic plus ferric iron alteration } & -0.47 & 0.47 & 0.56 & 0.49 & 0.19 & 0.04 & -0.39 & \\
\hline & $(0.002)$ & $(0.0002)$ & 0.0002 & $(0.001)$ & $(0.19)$ & $(0.79)$ & $(0.05)$ & \\
\hline & $N=23$ & $N=23$ & $N=23$ & $N=23$ & $N=23$ & $N=23$ & $N=14$ & \\
\hline \multirow[t]{3}{*}{ Quartz-sericite-pyrite (phyllic) } & -0.50 & 0.54 & 0.60 & 0.47 & 0.29 & 0.11 & -0.08 & \\
\hline & $(0.004)$ & $(0.002)$ & $(0.0005)$ & $(0.006)$ & $(0.09)$ & $(0.52)$ & $(0.83)$ & \\
\hline & $N=18$ & $N=18$ & $N=18$ & $N=18$ & $N=18$ & $N=18$ & $N=8$ & \\
\hline \multirow[t]{3}{*}{ Eof all Quartz-sericite-pyrite alteration } & -0.33 & 0.49 & 0.59 & 0.46 & 0.07 & 0.02 & -0.04 & \\
\hline & $(0.03)$ & $(0.001)$ & $(0.000007)$ & $(0.002)$ & $(0.3)$ & $(0.89)$ & $(0.87)$ & \\
\hline & $N=23$ & $N=21$ & $N=22$ & $N=23$ & $N=23$ & $N=23$ & $N=14$ & \\
\hline \multirow[t]{3}{*}{ Propylitic or carbonate rocks } & 0.23 & -0.05 & -0.04 & -0.34 & 0.07 & 0.04 & 0.08 & \\
\hline & $(0.18)$ & $(0.75)$ & $(0.83)$ & $(0.04)$ & $(0.69)$ & $(0.8)$ & $(0.69)$ & \\
\hline & $N=19$ & $N=18$ & $N=19$ & $N=19$ & $N=19$ & $N=19$ & $N=15$ & \\
\hline \multicolumn{9}{|l|}{ AVIRIS } \\
\hline \multirow[t]{3}{*}{ Quartz-sericite-pyrite alteration } & -0.45 & 0.48 & 0.66 & 0.35 & 0.03 & 0.24 & -0.6 & 0.33 \\
\hline & $(0.05)$ & $(0.03)$ & 0.003 & $(0.13)$ & $(0.94)$ & $(0.31)$ & $(0.22)$ & 0.14 \\
\hline & $N=12$ & $N=12$ & $N=12$ & $N=12$ & $N=12$ & $N=12$ & $N=5$ & $N=12$ \\
\hline \multirow[t]{3}{*}{ Quartz-alunite-pyropylitic alteration } & -0.52 & 0.14 & 0.52 & 0.14 & -0.14 & 0.04 & -0.66 & 0.14 \\
\hline & $(0.13)$ & $(0.76)$ & $(0.13)$ & $(0.76)$ & $(0.76)$ & (1) & $(0.30)$ & 0.76 \\
\hline & $N=7$ & $N=7$ & $N=7$ & $N=7$ & $N=7$ & $N=7$ & $N=4$ & $N=7$ \\
\hline \multirow[t]{3}{*}{$\sum$ of all NAP alteration } & -0.66 & 0.49 & 0.54 & 0.42 & 0.23 & 0.5 & -0.63 & 0.45 \\
\hline & $(0.0002)$ & $(0.006)$ & 0.0004 & $(0.03)$ & $(0.21)$ & $(0.008)$ & $(0.008)$ & 0.01 \\
\hline & $N=17$ & $N=17$ & $N=16$ & $N=16$ & $N=17$ & $N=16$ & $N=11$ & $N=17$ \\
\hline \multirow{3}{*}{$\begin{array}{l}\sum \text { of propylitic alteration: } \sum \text { of all NAP } \\
\text { alteration (ratio) }\end{array}$} & 0.63 & -0.42 & -0.53 & -0.34 & 0.13 & -0.34 & 0.64 & -0.28 \\
\hline & $(0.0001)$ & $(0.03)$ & $(0.010)$ & $(0.10)$ & $(0.52)$ & $(0.10)$ & $(0.01)$ & 0.16 \\
\hline & $N=15$ & $N=15$ & $N=14$ & $N=14$ & $N=15$ & $N=14$ & $N=10$ & $N=15$ \\
\hline
\end{tabular}

Values in bold indicate statistical trends

$P$ values are in parenthesis, $N$ is number of watersheds used in analyses

regression value $(R=0.63, n=40)$ is observed between area of propylitic rocks and total watershed area. Positive trends are also observed between area of propylitic alteration, stream length $(R=0.31, n=40)$, and non-vegetated area $(R=0.66, n=40)$.

Exclusion of mined watersheds resulted in very similar trends between area of qsp alteration, $\mathrm{pH}, \mathrm{Fe}$, and $\mathrm{Al}$ when compared with the dataset containing mined and unmined watersheds (Table 7). The largest increase in regression values in the unmined dataset was observed for both the $\sum$ all NAP alteration types and the ratio of propylitic to NAP alteration and water quality. The $\sum$ all NAP areas have a negative correlation with $\mathrm{pH}$ and alkalinity. Positive correlations were also observed for the $\sum$ all NAP areas, and $\mathrm{Fe}, \mathrm{Al}, \mathrm{Cu}$, specific conductance, and sulfate. The ratio Spropylitc: $\sum$ all NAP resulted in positive correlations 
Table 8 Linear regression coefficients for 30 m GIS stream buffered area intersecting alteration type and water quality parameters for mined and unmined watersheds

\begin{tabular}{|c|c|c|c|c|c|c|c|c|}
\hline Buffer alteration type & $\mathrm{pH}$ & $\mathrm{Fe}$ & Al & $\mathrm{Cu}$ & $\mathrm{Zn}$ & Specific conductance & $\mathrm{SO}_{4}$ & Alkalinity \\
\hline \multirow[t]{3}{*}{ Quartz-sericite-pyrite alteration buffer } & -0.40 & 0.25 & 0.36 & 0.48 & -0.12 & 0.03 & 0.03 & -0.73 \\
\hline & $(0.05)$ & $(0.23)$ & $(0.08)$ & $(0.01)$ & $(0.58)$ & 0.91 & $(0.91)$ & $(0.06)$ \\
\hline & $N=14$ & $N=14$ & $N=14$ & $N=14$ & $N=14$ & $N=14$ & $N=14$ & $N=6$ \\
\hline \multirow[t]{3}{*}{ Eof non propylitic alteration buffer } & -0.42 & 0.32 & 0.49 & 0.21 & 0.09 & 0.18 & 0.09 & -0.17 \\
\hline & $(0.007)$ & $(0.04)$ & 0.002 & $(0.17)$ & $(0.58)$ & 0.25 & $(0.59)$ & $(0.50)$ \\
\hline & $N=21$ & $N=21$ & $N=21$ & $N=21$ & $N=21$ & $N=21$ & $N=21$ & $N=12$ \\
\hline \multirow[t]{3}{*}{ Propylitic alteration buffer } & 0.17 & -0.07 & -0.01 & -0.02 & 0.09 & -0.05 & -0.11 & 0.14 \\
\hline & $(0.12)$ & $(0.50)$ & $(0.90)$ & $(0.83)$ & $(0.42)$ & 0.65 & $(0.33)$ & $(0.30)$ \\
\hline & $N=39$ & $N=39$ & $N=39$ & $N=39$ & $N=39$ & $N=39$ & $N=39$ & $N=28$ \\
\hline
\end{tabular}

GIS stream buffer was applied to hybrid, AVIRIS and field mapping data

Values in bold indicate statistical trends

$P$ values are in parenthesis, $N$ is number of watersheds used in analyses

Table 9 Linear regression coefficients for $30 \mathrm{~m}$ GIS stream buffered area intersecting alteration type and water quality parameters for unmined watersheds

\begin{tabular}{lllllllll}
\hline Buffer alteration type & $\mathrm{pH}$ & $\mathrm{Fe}$ & $\mathrm{Al}$ & $\mathrm{Cu}$ & $\mathrm{Zn}$ & Specific conductance & $\mathrm{SO}_{4}$ & $\mathrm{Alkalinity}$ \\
\hline Eof non propylitic alteration buffer & $\mathbf{- 0 . 4 8}$ & $\mathbf{0 . 4 5}$ & $\mathbf{0 . 6 7}$ & 0.38 & 0.12 & 0.36 & -0.73 & 0.24 \\
& $(0.03)$ & $(0.05)$ & 0.003 & $(0.09)$ & $(0.63)$ & 0.11 & $(0.30)$ & $(0.06)$ \\
& $N=12$ & $N=12$ & $N=12$ & $N=12$ & $N=12$ & $N=12$ & $N=12$ & $N=6$ \\
\hline
\end{tabular}

GIS stream buffer was applied to hybrid, AVIRIS and field mapping data

Values in bold indicate statistical trends

$P$ values are in parenthesis, $N$ is number of watersheds used in analyses

with $\mathrm{pH}$ and alkalinity. $\mathrm{Fe}$ and $\mathrm{Al}$ are negatively correlated with area of propylitically altered bedrock. Exclusion of mined watersheds does not increase the strength of morphometric correlations observed with area of propylitic alteration.

\section{Area of vegetation}

Correlations between non-vegetated and whole watershed areas of qsp alteration and water quality parameters were similar, both having negative correlations with $\mathrm{pH}$ $(R=-0.41, n=19)$ and positive correlations with $\mathrm{Fe}$ $(R=0.36, n=19)$ and $\mathrm{Al}(R=0.56, n=19)$. Area of nonvegetated qap is negatively correlated with $\mathrm{pH}(R=-0.51$, $n=12$ ) and has a similar negative correlation value that is also observed for whole watershed area of qap alteration.

Hybrid AVIRIS and field mapping data (30-m GIS stream-buffered area analysis)

Linear regression analysis was performed on the intersected area of alteration types along a 30-m GIS stream buffer and water quality signatures. Area statistics for
GIS-buffered areas of qsp alteration is in Table 3 (ESM only). In general, the stream buffered area analysis yielded weaker correlations compared with the total watershed area. Buffered area of qsp alteration is negatively correlated with $\mathrm{pH}$ (Table 8). Copper is also more highly correlated with GIS-buffered areas of qsp compared with whole watershed area analysis. Alkalinity is negatively correlated with area of qsp, although the small sample size $(n=6)$ requires additional data to confirm this correlation. The sum of NAP alteration is negatively correlated with $\mathrm{pH}$ and is positively correlated with $\mathrm{Al}$, with the regression value being higher for $\mathrm{Al}$ compared with whole watershed analysis. Correlations for $\mathrm{Fe}, \mathrm{Al}$, and alkalinity increased when mined watersheds were excluded from regression analysis (Table 9). GIS-buffered propylitic areas along streams are not correlative with either $\mathrm{pH}$ or alkalinity.

Factor analysis

\section{TM data}

A four factor model was used to explain $84 \%$ of the variance for TM data with factors one and two accounting 
for $60 \%$ of the variance (Table 4, ESM only). Factor 1 loadings (29\% of the variance) indicate the highest correlation for areas of iron and clay-sulfate-sericite alteration. There is also a corresponding, weak inverse correlation with alkalinity that is likely caused by the increased weathering of hydrothermally altered areas and possible lack of propylitic rocks that have ANC. Factor 2 represents $26 \%$ of the variance and has a weak negative correlation with the TM_Mod_Fe_2 classification defined by Rockwell (2010). Aluminum, $\mathrm{Fe}, \mathrm{SO}_{4}$, and specific conductance all have inverse correlations with $\mathrm{pH}$. Factor 2 loading scores are consistent with a correlation between increased area of iron alteration, corresponding low $\mathrm{pH}$ and an increase in major metal cations ( $\mathrm{Al}$ and $\mathrm{Fe}$ ), $\mathrm{SO}_{4}$, and specific conductance.

\section{ASTER data}

A six factor model was used to explain $92 \%$ of the variance for the ASTER dataset, with factors one and two accounting for $56 \%$ of the variance (Table 5, ESM only). Factor 1, with $33 \%$ of variance indicates a strong, positive correlation for areas of clay, ferric iron, and qsp alteration. The high correlations for $\mathrm{Al}$ and $\mathrm{Fe}$ are consistent with weathering of hydrothermally altered rocks in watersheds having abundant aluminum-bearing clay minerals in addition to oxidation of pyrite and other sulfide phases. Weak correlations are observed for $\mathrm{pH}$ and specific conductance that would be expected in these more highly altered watersheds. Factor 2 represents $24 \%$ of the variance and shows correlations between the multiple subtypes of propylitcally altered rocks mapped by ASTER. There is no associated correlation, however, between propylitic rocks and $\mathrm{pH}$. This finding could be a result of the limits of ASTER data in completely mapping a watershed because of vegetation cover that ultimately reduces the detectable area of propylitically altered bedrock having ANC. Factor 3 represents $12 \%$ of the variance with the metals (Fe, and $\mathrm{Al}), \mathrm{SO}_{4}$, and specific conductance being inversely correlated with $\mathrm{pH}$. Factor 4 represents $10 \%$ of the variance and shows correlations between $\mathrm{pH}, \mathrm{Cu}$, and $\mathrm{Zn}$. Correlative $\mathrm{Cu}$ and $\mathrm{Zn}$ is consistent with weathering of a base metal sulfide mineral assemblage containing copper and zinc sulfides that are common in polymetallic veins in the study area.

The importance of the propylitic assemblage in mitigating ARD can be inferred in factor 5 (9\% of variance). Low $\mathrm{pH}$ and low alkalinity are correlated with watersheds having a relatively small area of propylitic alteration. Thus, minimal ANC is supplied by propylitically altered rocks to mitigate NAP. Factor 6 , representing $5 \%$ of the variance has a weak positive correlation with $\mathrm{pH}$ and a corresponding positive correlation with the mixed, regional propylitic to weak qsp and minor sericite assemblage.
Metal concentrations $\mathrm{Al}$ and $\mathrm{Fe}$ are also negatively correlated. This suggests that ANC and possible decreased metal abundances attributed to weathering of propylitically altered rocks as part of this mixed assemblage overwhelms any NAP produced by the weak qsp and minor sericitebearing rocks.

\section{Hybrid AVIRIS and field data}

A six factor model was used to explain $80 \%$ of the variance in the hybrid AVIRIS- and field-based dataset (Table 6, ESM only). Factor 1 represents $24 \%$ of the variance and shows an inverse correlation between $\mathrm{pH}$ and the NAP alteration types argillic, qsp, qap, and $\sum$ qsp + qap. $\mathrm{Al}, \mathrm{Fe}$, and $\mathrm{Cu}$ concentrations, sulfate and specific conductance are inversely correlated with $\mathrm{pH}$. Factor 2 explains $24 \%$ of the variance and identifies positive correlations among the morphometric parameters of stream length, total area, and propylitically altered rocks. In addition, both vegetated, non-vegetated areas, and area of quaternary deposits are all positively correlated. Weaker positive correlations are observed for wsp and $\sum$ of all NAP. These patterns are consistent with large watersheds having an abundance of propylitically altered rocks and longer total stream lengths. Factor 3 explains $11 \%$ of the variance. Variables that are correlated include the NAP alteration types qsp, $\sum$ qsp + qap, wsp-hp and $\mathrm{Zn}$. It is uncommon that $\mathrm{Zn}$ is correlated with alteration variables mapped by the TM and ASTER datasets. Thus, hybrid AVIRIS-field maps may be a more useful tool in identifying possible impacts to water quality from weathering of mineralized areas containing base metals. Factor 4 represents $8 \%$ of the variance and shows correlations between sulfate and specific conductance. Factor 5, representing $8 \%$ of the variance shows correlations between the ratio Epropylitic: $\sum$ non-propylitic, $\mathrm{pH}$, and alkalinity. No correlation is observed for only the area of propylitically altered rocks indicating that the ratio of ANC (propylitic) to NAP (non-propylitic) is the controlling factor in determining alkalinity and $\mathrm{pH}$, and not just the area of ANC. Factor 6 consists of $6 \%$ of the variance and indicates a positive correlation between drainage density and wsp-hyd alteration. Wsp-hyd alteration may be more prone to weathering that could cause an increase in drainage density compared with other alteration types that do not show a similar trend.

\section{Discussion}

GIS was valuable in quantifying areas of alteration derived from TM, ASTER, and hybrid AVIRIS-field mapping datasets. While it is useful to characterize the primary 
igneous units that had formed prior to alteration, weathering of hydrothermally altered bedrock and associated mineral deposits is the primary cause of resultant water quality. This is because there are few igneous units in the study area that have not been altered to at least some degree, modifying the primary igneous minerals to a secondary alteration mineral assemblage. GIS analysis identified the study area as being comprised of $67 \%$ propylitic ANC rocks that are overprinted by $6 \%$ NAP rocks. The low NAP:ANC ratio is informative because it highlights that only a small proportion of NAP alteration is necessary to adversely impact water quality. Mining impacts that are usually coincident with areas of NAP alteration add to the acid and metal loads to surface water and groundwater. Where the NAP:ANC ratio is high, water quality impacts are severe that have toxic effects on aquatic life. Two basins with a high average NAP:ANC ratio are Mineral Creek and Cement Creek. Severe to acute $\mathrm{Al}, \mathrm{Cu}, \mathrm{Zn}$, and $\mathrm{Cd}$ toxicity is observed for trout and sensitive taxa in the Mineral and Cement Creek basins (Besser et al. 2007). In contrast to areas that are pervasively altered to NAP assemblages, watersheds having mostly vein-related mineralization are characterized by alteration confined to narrow zones adjacent to veins that do not pervade adjacent propylitic rocks. The south Silverton mining area contains several watersheds with prevalent vein-related mineralization. GIS analysis delineates small areas of NAP alteration in the south Silverton mining area and large areas of propylitic alteration consistent with water quality having neutral $\mathrm{pH}$, and low metal concentrations with the exception of $\mathrm{Zn}$ in some watersheds that can locally sustain trout (Besser et al. 2007).

The average elevation of propylitically altered rocks relative to the mean watershed elevation determined by GIS was found to be an important factor affecting water quality. Less acidic to neutral watersheds tend to have propylitically altered rocks that form at an average elevation that is higher than the mean watershed elevation. In contrast, the average elevation of propylitically altered rocks in acidic watersheds is usually lower than the mean watershed elevation. When propylitically altered rocks occur at high elevations in mountain watersheds where precipitation is commonly greater and snow melt is more persistent throughout the spring and summer, this provides a consistent source of alkalinity to help mitigate ARD.

A watershed grouping schema was developed for mined and unmined watersheds using a limited numbers of variables including alteration type area determined using GIS analysis of AVIRIS data, surface water $\mathrm{pH}$ at watershed outlets, historical records, and field observations. Land managers could benefit from such a schema that would aid in quickly assessing watersheds in terms of possible geoenvironmental impacts. This analysis used $\mathrm{pH}$ data because it is a quickly acquired field parameter that can also be a proxy for other water quality impacts such as high metal and sulfate concentrations. Five watershed groupings were determined based on similarities in $\mathrm{pH}$, area affected by NAP alteration, and mining impacts (Fig. 9). Group 1 watersheds may represent the best case scenario for possible reclamation success and mitigating mining impacts due to the large watershed size and low NAP:ANC ratio. In contrast, a high NAP:ANC ratio for group 5 watersheds may pose the greatest geoenvironmental challenges due to acidic surface water conditions that existed prior to mining. Mining impacts for group 3 watersheds are clearly delineated due to the low NAP:ANC ratio, yet having acidic $\mathrm{pH}$. Group 2 and 4 watersheds have minimal mining impacts and have acidic surface water quality because of varying proportions of NAP alteration. This type of grouping could aid in prioritizing reclamation resources for geoenvironmental cleanup and also aid mining companies in identifying watershed NAP and ANC characteristics. Where information about specific mineral deposit types is also known, a prediction of the types of water quality impacts could be more completely discerned.

Statistical analysis in this study was effective in determining the association between watershed characteristics and water quality signatures. Previous preliminary studies also established correlations between water quality and areas of alteration mapped using the hybrid AVIRIS- and field-based data (Yager et al. 2008a, b). It was not known, however, whether less detailed alteration maps derived from TM and ASTER would also be effective in determining correlations with watershed properties. Analysis in this study revealed correlations with water quality parameters despite relatively small percentages of watershed areas being mapped by TM and ASTER alteration datasets because of vegetation cover. This has important implications for national geoenvironmental and mineral assessments, especially in areas of the western United States that are more suitable to spectral mapping by remote sensing methods because the western regions are often not as highly vegetated as eastern US terrain.

Linear regression analysis identified correlations between mineral groups mapped by TM (TM-CSM, TM-Fe), major metal cations $(\mathrm{Fe}, \mathrm{Al})$ in surface water and low $\mathrm{pH}$. These results were achieved despite a relatively small watershed area being mapped by TM. TM data are available for the entire US and suggest that when more detailed mineral maps are not available, TM could be useful in identifying potential water quality impacts from hydrothermally altered areas. ASTER was able to map a larger watershed area compared with TM and linear regression analysis revealed correlations between Aster-Arg-Fe, Aster-qsp, major metal cations $(\mathrm{Fe}, \mathrm{Al})$ in surface water and low $\mathrm{pH}$. ASTER data are also available for the entire US and when 
Fig. 9 Watersheds grouped based on percent NAP alteration area, mining impacts, and $\mathrm{pH}$. Group 1 (green) have 10-20\% NAP area, are mining impacted, and $\mathrm{pH}$ ranging from 5.07 to 5.21; Group 2 (yellow) have $30-40 \%$ NAP, have minimal mining impacts, and $\mathrm{pH}$ ranging from 3.58 to 4.88 ; Group 3 (coral) have $<10 \%$ NAP, are mining impacted, and $\mathrm{pH}$ ranging from 2.88 to 4.19 ; Group 4 (light blue) have 50-100 \% NAP, have minimal mining impacts, and $\mathrm{pH}$ ranging from 3.45 to 3.90; Group 5 (red) have $50-85 \%$ NAP, are mining impacted, and $\mathrm{pH}$ ranging from 3.04 to 3.89 . Watershed id's correspond with those labeled in Fig. 2

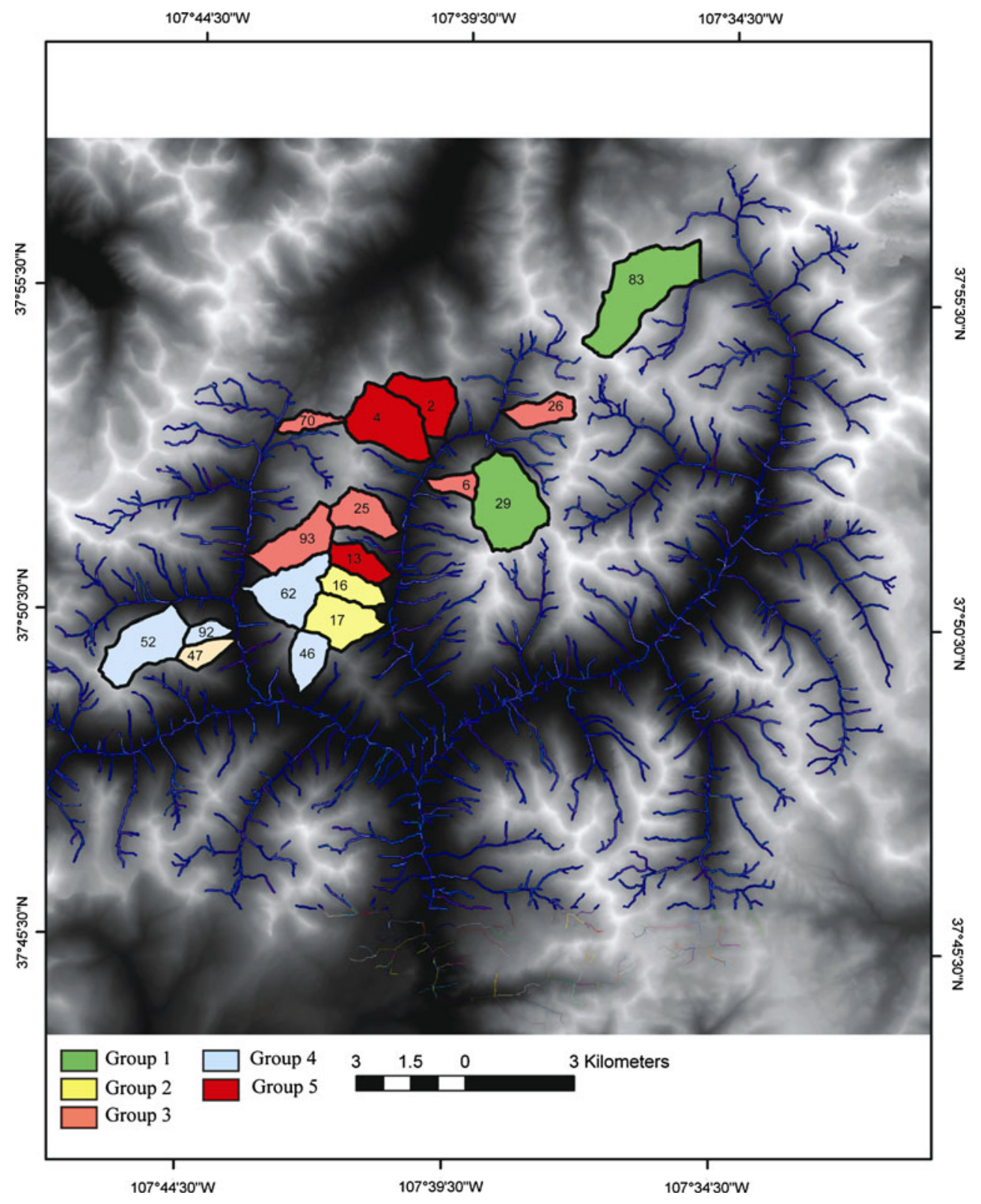

more specific mineralogic data such as the presence of propylitic rocks containing acid neutralizing assemblages calcite and chlorite are required, ASTER can be used to augment mapping by TM. In general, correlations between NAP assemblages and water quality signatures are improved when mining impacted watersheds were excluded from analysis, suggesting that the GIS and statistical methods used in this study could be effective in unmined and hydrothermally altered areas to identify possible naturally occurring sources of acidity and metals to surface water.

AVIRIS mineral mapping have the most complete watershed area coverage and the highest correlations in regression analysis. The area of qsp was determined to have the highest correlations with major metal cations $(\mathrm{Fe}$, Al) and low pH. Quartz-alunite-pyrophyllite and argillic alteration types mapped by AVIRIS are each correlated with low $\mathrm{pH}$. Argillic rocks are also correlated with aluminum. Correlations were also observed between increasing areas of propylitic rocks mapped by AVIRIS, watershed area, increasing $\mathrm{pH}$ and alkalinity. Similar correlations using propylitic bedrock mapping by ASTER were lacking that is likely due to the much smaller watershed area mapped by ASTER. This suggests that to understand the acid neutralizing capacity of a watershed, more complete watershed area mapping is required.

Statistical correlations are generally higher for whole watershed area analysis when compared to linear correlations 
that involve analysis of altered areas intersected by a $30-\mathrm{m}$ GIS stream buffer. In-stream processes were hypothesized as possibly being more important in controlling water quality signatures because of the effectiveness that the hydrologic stream network has in conveying sediment and associated contaminants to watershed outlets. In general, altered areas intersected by a GIS buffer were less highly correlated compared with alteration areas calculated for whole watersheds. This finding suggests that the whole watershed analysis is a better geochemical integrator of water quality signatures derived from weathering of hydrothermally altered areas. Most watersheds near Silverton, Colorado have steep slopes; therefore, physical and chemical weathering work to effectively transport sediment and simultaneously leach contaminants to streams throughout the entire area. A GIS stream buffer, if applied to a lower gradient region, may result in higher correlations with water quality signatures compared to steep terrain because downslope slumping and transport of sediment may be less important in rapidly conveying sediment to streams allowing for a greater water-sediment contact time.

Factor analysis allowed trace metal patterns to be identified that are consistent with weathering of sulfidebearing hydrothermally altered areas. Only correlations between $\mathrm{Cu}$ and selected alteration assemblages were identified in linear regression analysis. Thus, correlations with other trace metals besides $\mathrm{Cu}$ in factor analysis is significant because it identified associated geoenvironmetal indicators that were predicted based on the mineral deposit types that are prevalent in the study area. An example of base metal correlations is observed for the ASTER data set in which $\mathrm{Cu}$ and $\mathrm{Zn}$ are inversely correlated with $\mathrm{pH}$, reflecting increased trace metal abundances with acidic conditions. Patterns were also identified in factor analysis of AVIRIS data involving propylitically altered areas. In these analyses, the ratio ANC:NAP is correlated with $\mathrm{pH}$ and alkalinity, highlighting the importance of the relative proportions of acid neutralizing- and net acid producingrocks in controlling acidity.

\section{Conclusions}

This analysis methodology emphasizes the importance of watersheds as key geographic units for interpreting water quality signatures in a geologic and morphometric context. Sampling strategies devised when a project is initiated could maximize the potential benefits of watershed scale analysis. Such a strategy would involve sampling watersheds of interest at the outlet during base flow conditions when concentrations of contaminants are not diluted by snowmelt or high precipitation. Analyses of watershed outlet samples would provide integrated geochemical information for all up-stream contributing areas, and constituents measured would be a result of the water-soilatmosphere interactions along the entire upstream flow path. Standard field parameters would be collected including $\mathrm{pH}$, specific conductance, dissolved oxygen, alkalinity, in addition to metal cations, anions, and sulfate. Mapping of geology, alteration, vegetation, terrain, and delineation of the hydrologic network would permit each watershed or basin to be well characterized and subsequently analyzed with GIS tools. Resultant data for watershed physical characteristics compiled from GIS would provide a basis for statistical analysis. This methodology would likely be valuable, especially in unmined areas, because the information acquired would begin to establish a geochemical baseline that could be compared to data collected once mining began or ceased. This approach would also enable watersheds to be ranked as to potential geoenvironmental impacts prior to and after mining.

Future analysis requires that basin-scale $(10 \mathrm{~s}$ to $100 \mathrm{~km}^{2}$ ) areas be analyzed using a GIS and statistical methodology similar to that used in this study. In order to upscale to larger areas, conservative geochemical constituents that are collected at basin outlets will need to be evaluated. Sulfate, $\mathrm{pH}$, or major metal cations ( $\mathrm{Al}$ and $\mathrm{Fe})$ may provide the best evidence for large-scale impacts to water quality from hydrothermally altered and mineralized areas. Geochemical data determined for stream sediments collected as part of the National Uranium Resource Evaluation (NURE) or during USGS Bureau of Land Management mineral assessment studies may be useful datasets for up-scaling. The stream sediments, while not providing a direct link to water quality effects, may provide an indication of possible bioavailable elements that could potentially impact water quality and aquatic life.

Acknowledgments The authors wish to thank the USGS, Animas abandoned mine lands (AML) team members who all provided useful discussions and data during preparation of this report. Special thanks to Stanley E. Church (USGS, ret.) who co-led the successful AML program. The Animas River Stakeholders Group, led by William Simon was inspirational in addressing watershed and mining-related issues in Silverton between 1996 and present. Roland J. Viger (USGS) provided useful guidance in using the GIS Weasel software. Denise Dundon provided GIS support. USGS reviewers Mary Ellen Benson, Eric Anderson and two anonymous external reviewers provided useful critique of this work. This study was supported by the U.S. Geological Survey Mineral Resources Program, the Mineral Environmental Assessment Methodologies Project and the Central Mineral and Environmental Resources Science Center. Any use of trade, product, or firm names is for descriptive purposes only and does not imply endorsement by the US Government.

Open Access This article is distributed under the terms of the Creative Commons Attribution License which permits any use, distribution, and reproduction in any medium, provided the original author(s) and the source are credited. 


\section{References}

Bejnar W (1957) Lithologic control of ore deposits in the southwestern San Juan Mountains. In: Kottlowski FE, Baldwin B (eds) Guidebook of southwestern San Juan Mountains, Colorado. New Mexico Geological Society 8th Annual Field Conference Guidebook, pp 162-173

Besser JM, Finger SE, Church SE (2007) Impacts of historical mining on aquatic systems-An ecological risk assessment, chapter D. In: Church SE, von Guerard P, Finger SE (eds) Integrated investigations of environmental effects of historical mining in the Animas River watershed, San Juan County, Colorado. U.S. Geological Survey Professional Paper 1651, pp 87-106

Bove DJ, Hon K, Budding KE, Slack JF, Snee LW, Yeoman RA (2001) Geochronology and geology of late Oligocene through Miocene volcanism and mineralization in the western San Juan Mountains, Colorado. U.S. Geological Survey Professional Paper 1642

Bove DJ, Yager DB, Mast MA, Dalton JB (2007a) Alteration map showing major faults and veins and associated water-quality signatures of the Animas River watershed headwaters near Silverton, southwest Colorado. U.S. Geological Survey Scientific Investigations Map 2976, 18-p pamphlet, 1 plate, scale $1: 24,000$

Bove DJ, Mast MA, Dalton JB, Wright WG, Yager DB (2007b) Major styles of mineralization and hydrothermal alteration and related solid and aqueous-phase geochemical signatures, chapter E3. In: Church SE, von Guerard, P, Finger SE (eds) Integrated Investigations of Environmental Effects of Historical Mining in the Animas River Watershed, San Juan County, Colorado. U.S. Geological Survey Professional Paper 1651, pp 161-230

Bruns DA (2005) Macroinvertebrate response to land cover, habitat, and water chemistry in a mining-impacted river ecosystem: $1 \mathrm{~A}$ GIS watershed analysis. Aquat Sci 67:403-423

Burbank WS (1960) Pre-ore propylization, Silverton Caldera, Colorado. In: Geological Survey Research 1960. U.S. Geological Survey Professional Paper 400-B, article 6, pp B12-B13

Casadevall TJ, Ohmoto H (1977) Sunnyside Mine, Eureka mining district, San Juan County, Colorado-Geochemistry of gold and base metal ore deposition in a volcanic environment. Econ Geol 92:1285-1320

Chapman SS, Griffith GE, Omernik JM, Price AB, Freeouf J, Schrupp DL (2006) Ecoregions of Colorado (color poster with map, descriptive text, summary tables, and photographs). Reston, Virginia, U.S. Geological Survey (map scale 1:1,200,000)

Church SE, von Guerard P, and Finger SE (eds) (2007) Integrated investigations of environmental effects of historical mining in the Animas River watershed, vol 1, 2. San Juan County, Colorado. U.S. Geological Survey Professional Paper 1651

Clow DW, Sucker JK (2000) Relations between basin characteristics and stream water chemistry in alpine/subalpine basins in Rocky Mountain National Park, Colorado. Water Resour Res 36(1):49-61

Dalton JB, Bove DJ, Mladinich CS, Rockwell BW (2007) Imaging spectroscopy applied to the Animas River watershed and Silverton caldera, chapter E2. In: Church SE, von Guerard P, Finger SE (eds) Integrated investigations of environmental effects of historical mining in the Animas River watershed, San Juan County, Colorado. U.S. Geological Survey Professional Paper 1651, pp 141-159

DeGraff JV (2007) Addressing the toxic legacy of abandoned mines on public land in the western United States. Rev Eng Geol $17: 1-8$

Earth Remote Sensing Data Analysis Center (ERSDAC) (2005) ASTER user's guide, part 1, General, Version 4.0: http://www.science.aster.ersdac.jspacesystems.or.jp/en/documnts/ users_guide/part1/pdf/Part1_4E.pdf. Accessed 8 November 2012

Helsel DR, Hirsch RM (2002) Statistical Methods in water resources: techniques of water resources investigations, book 4, chapter A3. U.S. Geological Survey

Hunt GR, Salisbury JW (1970) Visible and near-infrared spectra of minerals and rocks, I. Silicate minerals. Mod Geol 1:283-300

Hunt GR, Salisbury JW (1971) Visible and near-infrared spectra of minerals and rocks, II. Carbonates. Mod Geol 2:23-30

Jenson SK, Domingue JO (1988) Software tools to extract topographic structure from digital elevation data for geographic information system analysis: photogramm. Eng Remote Sens 54(11):1593-1600

Johnson RH (2007) Ground water flow modeling with sensitivity analyses to guide field data collection in a mountain watershed. Ground Water Monit Remediat 27(1):75-83

Johnson RH, Yager DB (2006) Completion reports, core logs, and hydrologic data from wells and piezometers in Prospect gulch, San Juan County, Colorado. U.S. Geological Survey Open-File Report, of 2006-1030

Kendall MG (1975) Rank correlation methods, 4th edn. Charles Griffin, London, p 202

Kimball BA, Walton-Day K, Runkel RL (2007) Quantification of metal loading by tracer injection and synoptic sampling, 1996-2000, Chapter E9: In: Church SE, von Guerard P, Finger SE (eds) Integrated investigations of environmental effects of historical mining in the Animas River watershed, San Juan County, Colorado. U.S. Geological Survey Professional Paper 1651, pp 417-495

Kinnell PIA (2005) Raindrop-impact-induced erosion processes and prediction: a review. Hydrol Process 19:2815-2844

Leib KJ, Mast MA, Wright WG (2007) Characterization of mainstem streams using water-quality profiles, chapter E11. In: Church SE, von Guerard P, Finger SE (eds) Integrated investigations of environmental effects of historical mining in the Animas River watershed, San Juan County, Colorado. U.S. Geological Survey Professional Paper 1651, pp 543-570

Mast MA, Evans JB, Leib KJ, Wright WG (2000a) Hydrologic and water-quality data at selected sites in the upper Animas River watershed, southwestern Colorado, 1997-99. U.S. Geological Survey Open-File Report 2000-53

Mast MA, Verplanck PL, Yager DB, Wright WG, Bove DJ (2000b) Natural sources of metals to surface waters in the Upper Animas River Watershed, Colorado. In: Proceedings of the 5th International Conference on acid-rock drainage (ICARD). Society for Mining, Metallurgy, and Exploration, pp 513-522

Mast MA, Verplanck PL, Wright WG, Bove DJ (2007) Characterization of background water quality, chapter E7. In: Church SE, von Guerard, P, Finger, SE (eds) Integrated investigations of environmental effects of historical mining in the Animas River watershed, San Juan County, Colorado. U.S. Geological Survey Professional Paper 1651, pp 347-386

O'Callaghan JF, Mark DM (1984) The extraction of drainage networks from digital elevation data. Comput Vis Graph Image Process 28:323-344

Rockwell BW (2009) Comparison of ASTER- and AVIRIS-derived mineral and vegetation maps of the White Horse replacement alunite deposit and surrounding area, Marysvale volcanic field, Utah. U.S. Geological Survey Scientific Investigations Report 2009-5117. http://pubs.usgs.gov/sir/2009/5117/. Accessed 8 November 2012

Rockwell BW (2010) Evaluation of detailed and automated methodologies for hydrothermal alteration mapping from space: application to geoenvironmental and mineral resource assessments at the scale of watersheds and permissive tracts. Geol Soc Am Abstr Program 42(5):214. Presentation handout at: 
http://gsa.confex.com/gsa/2010AM/finalprogram/abstract_1798 92.htm. Accessed 8 November 2012

Schmidt TS, Church SE, Clements WH, Mitchell K, Fey DL, Wanty RB, Verplanck PL, San Juan CA, Klein TL, DeWitt EH, Rockwell BW (2009) Geologic processes influence the effect of mining on aquatic ecosystems. In: Webb RMT, Semmens DJ (eds) Planning for an uncertain future-monitoring, integration, and adaptation. Proceedings of the Third Interagency Conference on Research in the Watersheds. U.S. Geological Survey Scientific Investigations Report 2009-5049

Schmidt TS, Wanty RB, Verplanck PL, Church SE, San Juan CA, Fey D, Rockwell BW, deWitt EH, Klein TL (2010) Predicting risks to aquatic life based on lithologic specific geochemical baselines. Geol Soc Am Abstr Program 42(5):214

Sliva L, Williams D (2001) Buffer zone versus whole catchment approaches to studying land use impact on river water quality. Water Res 35(14):3462-3472

Smith BD, McDougal RR, Deszcz-Pan M, Yager DB (2007) Helicopter electromagnetic and magnetic surveys, Chapter E4. In: Church SE, von Guerard P, Finger SE (eds) Integrated investigations of environmental effects of historical mining in the Animas River watershed, San Juan County, Colorado. U.S. Geological Survey Professional Paper 1651, pp 231-254

Sole, TC, Grannito, Matthew, Rich, CL, Litke DW, Pelltier RT (2007) Digital databases and CD-ROM for the Animas River watershed, Chapter G. In: Church SE, von Guerard P, Finger SE (eds) Integrated investigations of environmental effects of historical mining in the Animas River watershed, San Juan County, Colorado. U.S. Geological Survey Professional Paper 1651, pp 1079-1096

Theil H (1950) A rank-invariant method of linear and polynomial regression analysis, vol 1,2, and 3. Ned. Akad. Wentsch Proc., 53:386-392, 521-525, and 1397-1412

Varnes DJ (1963) Geology and ore deposits of the south Silverton mining area, San Juan County, Colorado. U.S. Geological Survey Professional Paper 378-A

Viger RJ (2008) The GIS Weasel: an interface for the development of geographic information used in environmental simulation modeling. Comput Geosci 34(8):891-901

Viger RJ, Leavesley GH (2007) The GIS Weasel user's manual. U.S. Geological Survey Techniques and Methods, book 6, chapter B4. http://pubs.usgs.gov/tm/2007/06B04/. Accessed 8 November 2012

Viger RJ, Markstrom SL, Leavesley GH (1998) The GIS Weasel-an interface for the treatment of spatial information used in watershed modeling and water resources management. In: Proceedings of the First Federal Interagency Hydrologic Modeling Conference, April 19-23, 1998, Las Vegas, Nev., 2(7):73-80

Wang X, Yin ZY (1997) Using GIS to assess the relationship between land use on water quality at a watershed level. Environ Int 23:103-114

Wright WG, Simon W, Bove DJ, Mast MA, Leib KJ (2007) Distribution of $\mathrm{pH}$ values and dissolved trace-metal concentrations in streams, Chapter E10. In: Church SE, von Guerard P, Finger SE (eds) Integrated investigations of environmental effects of historical mining in the Animas River watershed, San Juan County, Colorado. U.S. Geological Survey Professional Paper 1651, pp 497-541

Yager DB (2008) Environmental rock properties at abandoned mine lands that generate or neutralize acid drainage, Silverton, Colorado, chapter K. In: Verplanck PL (ed) Understanding contaminants associated with mineral deposits. U.S. Geological Survey Circular 1328, pp 64-69

Yager DB, Bove DJ (2002) Generalized geologic map of the Upper Animas River Watershed and Vicinity, Silverton, Colorado. U.S. Geological Survey Miscellaneous Field Studies Map MF-2377, U.S. Geological Survey, Denver, CO, scale 1:48,000

Yager DB, Bove DJ (2007) Geologic framework, chapter E1. In: Church SE, von Guerard P, Finger SE (eds) Integrated investigations of environmental effects of historical mining in the Animas River watershed, San Juan County, Colorado. U.S. Geological Survey Professional Paper 1651, pp 107-140

Yager DB, Caine JS (2003) GIS analysis of the fundamental geologic, topographic, and mining-related factors that influence water quality in the upper Animas River watershed, Silverton, Colorado. Geological Society of America, Rocky Mountain Section, 55th Annual Meeting Abstr. Program. 35(5):6

Yager DB, Mast MA, Verplanck PL, Bove DJ, Wright WG, Hageman PL (2000) Natural versus mining-related water quality degradation to tributaries draining Mount Moly, Silverton, CO. In: Proceedings of the Fifth International Conference on Acid Rock Drainage, Society for Mining, Metallurgy, and Exploration, Inc., Littleton, pp 535-547

Yager DB, Caine JS, Bove DJ, Church SE, Smith BD, Mcdougal RR, Wirt L, Mast MA, Kimball BA, Walton-Day K (2002) A GIS data viewer for physical and geochemical characterization of abandoned mine lands: an example from the Animas River watershed, Silverton, Colorado. Geol Soc Am Annu Meet Abstr Program 34(6): 145

Yager DB, McCafferty AE, Stanton MR, Diehl SF, Driscoll RL, Fey DL, Sutley SJ (2005) Net acid production, acid neutralizing capacity, and associated geophysical, mineralogical, and geochemical characteristics of Animas River watershed rocks near Silverton, Colorado. U.S. Geological Survey Open-File Report 2005-1433

Yager DB, Choate L, Stanton MR (2008) Net acid production, acid neutralizing capacity, and associated mineralogical and geochemical characteristics of Animas River watershed igneous rocks near Silverton, Colorado. U.S. Geological Survey Scientific Investigations Report 2008-5063

Yager DB, Johnson RH, Smith BD (2008) Using a geographic information system (GIS) to determine the physical factors that affect water quality in the western San Juan Mountains, Silverton, Colorado, chapter M. In: Verplanck PL (ed) Understanding contaminants associated with mineral deposits. U.S. Geological Survey Circular 1328, pp 76-83

Yager DB, Stanton MR, Choate LM, Burchell A (2009) Acid neutralizing capacity and leachate results for igneous rocks, with associated carbon contents of derived soils, Animas AML site, Silverton, Colorado. In: Barnheisel RI (ed) Revitalizing the Environment: Proven Solutions and Innovative Approaches: National Meeting of the American Society of Mining and Reclamation, Billings, MT, May 30-June, 5, 2009, ASMR publication, Lexington, pp 1662-1697

Yager DB, Burchell A, Johnson RH (2010) A geologic and anthropogenic journey from the Precambrian to the new energy economy through the San Juan volcanic field. In: Morgan LA, Quane SL (eds) Through the Generations: Geologic and Anthropogenic Field Excursions in the Rocky Mountains from Modern to Ancient: Geol Soc Am, Field Guide 18, pp 193-237 